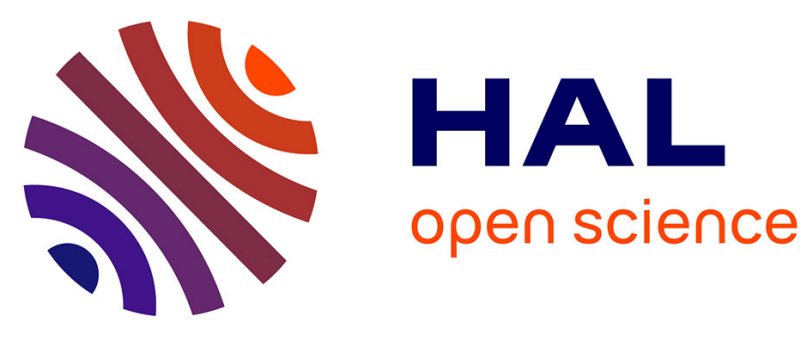

\title{
A portable infrared laser spectrometer for flux measurements of trace gases at the geosphere-atmosphere interface
}

Christophe Guimbaud, Valéry Catoire, Sébastien Gogo, Cédric Robert Robert, M. Chartier, Fatima Laggoun-Défarge, A. Grossel, Patrick Albéric, L. Pomathiod, Bernard Nicoullaud, et al.

\section{To cite this version:}

Christophe Guimbaud, Valéry Catoire, Sébastien Gogo, Cédric Robert Robert, M. Chartier, et al.. A portable infrared laser spectrometer for flux measurements of trace gases at the geosphereatmosphere interface. Measurement Science and Technology, 2011, 22 (7), pp.1-17. 10.1088/09570233/22/7/075601 . insu-00595203

\section{HAL Id: insu-00595203 \\ https://hal-insu.archives-ouvertes.fr/insu-00595203}

Submitted on 24 Jun 2011

HAL is a multi-disciplinary open access archive for the deposit and dissemination of scientific research documents, whether they are published or not. The documents may come from teaching and research institutions in France or abroad, or from public or private research centers.
L'archive ouverte pluridisciplinaire HAL, est destinée au dépôt et à la diffusion de documents scientifiques de niveau recherche, publiés ou non, émanant des établissements d'enseignement et de recherche français ou étrangers, des laboratoires publics ou privés. 


\title{
A portable infrared laser spectrometer for flux measurements of trace gases at the geosphere-atmosphere interface
}

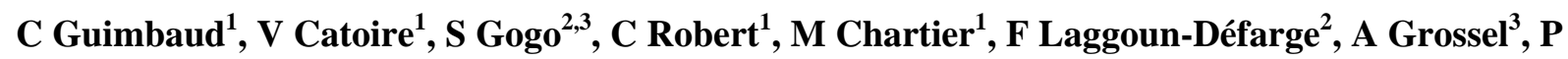 \\ Albéric $^{2}$, L Pomathiod ${ }^{1}$, B Nicoullaud ${ }^{3}$ and G Richard ${ }^{3}$
}

Correspondence to: C. Guimbaud (christophe.guimbaud@cnrs-orleans.fr)

[1] Laboratoire de Physique et Chimie de l'Environnement et de l'Espace (LPC2E), UMR 6115 CNRS-Université d'Orléans, 3A Avenue de la Recherche Scientifique, 45071 Orléans Cedex 2, France

[2] Institut des Sciences de la Terre d'Orléans (ISTO), UMR 6113 CNRS-Université d'Orléans, 1A rue de la Férolerie, 45071 Orléans Cedex 2, France

[3] INRA, UR0272 - Unité Science du Sol, Centre de recherche d'Orléans, 2163 Avenue de la Pomme de Pin, CS 40001 Ardon, 45075 Orléans Cedex 2, France

\begin{abstract}
A portable infrared laser absorption spectrometer named SPIRIT (SPectromètre Infra-Rouge In situ Troposphérique) has been set up for the simultaneous flux measurements of trace gases at the geosphere-atmosphere interface. It uses a Continuous Wave (CW) Distributed FeedBack (DFB) Room Temperature (RT) Quantum Cascade Laser (QCL) and a patented new optical multi-pass cell. The aim of SPIRIT field studies is to get a better understanding of lands and water bodies to atmosphere exchange mechanisms of GreenHouse Gases (GHG). The analytical procedure to derive concentrations and fluxes are described, as well as the performances of the instrument under field conditions. The ability of SPIRIT to assess space and time dependence emissions of two GHG nitrous oxide $\left(\mathrm{N}_{2} \mathrm{O}\right)$ and methane $\left(\mathrm{CH}_{4}\right)$ - for different types of ecosystems is demonstrated through in situ measurements on a peatland, on a fertilized soil, and on water body systems. The objectives of these investigations and preliminary significant results are reported.
\end{abstract}


Keywords: infrared spectroscopy, Quantum Cascade Lasers, Infrared spectrometry, SPIRIT, $\mathrm{CH}_{4}$, $\mathrm{N}_{2} \mathrm{O}$, flux measurements, chamber method, peatlands, water bodies, fertilized soils

\section{Introduction}

\subsection{Interest for the $\mathrm{CH}_{4}$ and $\mathrm{N}_{2} \mathrm{O}$ monitoring at ground level}

Global warming observed since the last century is mainly due to the anthropogenic increase of the three main long-lived GreenHouse Gases (GHG), namely carbon dioxide $\left(\mathrm{CO}_{2}\right)$, methane $\left(\mathrm{CH}_{4}\right)$ and nitrous oxide $\left(\mathrm{N}_{2} \mathrm{O}\right)$. Atmospheric volume mixing ratios for $\mathrm{CO}_{2}, \mathrm{CH}_{4}$ and $\mathrm{N}_{2} \mathrm{O}$ have raised from 275 to $379 \mathrm{ppm}$, from 715 to $1774 \mathrm{ppb}$ and from 270 to $319 \mathrm{ppb}$, respectively, between 1750 (preindustrial era) and 2005 (IPCC $4^{\text {th }}$ assessment report, 2007a). Despite the smaller absolute concentration raises observed for $\mathrm{CH}_{4}$ and $\mathrm{N}_{2} \mathrm{O}$ relative to $\mathrm{CO}_{2}, \mathrm{CH}_{4}$ and $\mathrm{N}_{2} \mathrm{O}$ emissions contribute significantly to current global warming and future trends for climate change because $\mathrm{CH}_{4}$ and $\mathrm{N}_{2} \mathrm{O}$ have a Global Warming Potential (GWP) averaged over 100 years of 25 and 298, respectively, relative to $\mathrm{CO}_{2}$. Climate change magnitude in the next decades is mainly driven by the unknown future rate of atmospheric concentration increase of $\mathrm{CO}_{2}, \mathrm{CH}_{4}$ and $\mathrm{N}_{2} \mathrm{O}$ and other minor trace gases.

Biogeochemical emissions represent a significant part of the atmospheric sources of these GHG (IPCC $4^{\text {th }}$ assessment report, 2007b,c). Wetlands (such as peatlands) and cultivated soils contribute to a large part of the $\mathrm{CH}_{4}$ and $\mathrm{N}_{2} \mathrm{O}$ emission budget, respectively. $\mathrm{CH}_{4}$ and $\mathrm{N}_{2} \mathrm{O}$ emissions from these ecosystems exhibit strong changes within a short time scale in response to direct anthropogenic perturbations or to climate changes. Feedbacks in response to direct anthropogenic perturbations can be: sensitivity of peatland $\mathrm{CH}_{4}$ emissions to drainage, to nutrient inputs from agriculture, or to peat extraction; sensitivity of cultivated soil $\mathrm{N}_{2} \mathrm{O}$ emissions to mineral fertilizers or organic manure inputs, to soil labour (ploughing, compaction), to watering, or to crops and soils nature. Feedbacks in response to climate changes can be: net peatland carbon storage and $\mathrm{CH}_{4}$ emissions changes, in response to temperature, soil humidity and biodiversity changes; sensitivity of $\mathrm{N}_{2} \mathrm{O}$ emissions from soils to rainfall and temperature changes.

$\mathrm{N}_{2} \mathrm{O}$ and $\mathrm{CH}_{4}$ are mainly produced by the naturally occurring microbial processes of incomplete denitrification or nitrification, and by strictly anaerobic methanogenesis. However, their production processes in soils and the transport mechanisms at the biogeosphere-atmosphere interface are poorly understood. As a consequence, gas fluxes must be understood in terms of (i) biological (microbial and vegetation) trace gas production/consumption including symbiosis processes and (ii) the physics of transport from soils and plants. Within an ecosystem, $\mathrm{N}_{2} \mathrm{O}$ and $\mathrm{CH}_{4}$ emissions are known to be strongly space (vegetation and soil properties) and time (diurnal and seasonal) dependent as it is the 
case for crop fields (Laville et al., 1999; Flessa et al., 2002) and peatlands (Bortolluzi et al., 2006; Comas et al., 2008; Hendriks et al., 2010) with different efflux pathways for peatlands and water bodies (diffusive or sudden bubbling events). The implication is that fluxes of $\mathrm{N}_{2} \mathrm{O}$ and $\mathrm{CH}_{4}$ need to be measured at a local scale with a short integration time (even if chamber methods are used to measure fluxes).

An infrared (IR) laser portable absorption spectrometer called SPIRIT (SPectromètre Infra-Rouge In situ Troposphérique) has been developed for simultaneous volume mixing ratios and flux measurements of the main GHG and other trace gases of interest with significant impacts on the oxidation capacity of the atmosphere. SPIRIT mobility, rapidity for integrating atmospheric trace gases concentration, and sensitivity to cover a wide range of possible flux intensities are its major advantages to enable space and time dependence emissions investigations and detailed processoriented studies of flux emissions (as a function of biota composition or abiotic parameters). SPIRIT instrument is designed to support three Quantum Cascade Lasers (QCL) operating at chosen wavelengths in the infrared region, depending on the type of the species measured. SPIRIT is currently equipped with one QCL operating for the detection of $\mathrm{CH}_{4}$ and $\mathrm{N}_{2} \mathrm{O}$ as a first step of concept validation, and because these two GHG gases (i) have a strong feedback in climate change in response to emissions changes from the geosphere and (ii) are challenging species to monitor. Their concentrations in ambient air and their emissions from ecosystems are indeed lower than those of $\mathrm{CO}_{2}$, and many cost effective instruments easy to handle do exist for $\mathrm{CO}_{2}$ monitoring.

\subsection{Current IR spectrometers and main strengths of SPIRIT}

IR absorption spectrometry provides the fastest online analysers for atmospheric trace gas concentration measurements. The very high resolution IR absorption spectrometry, possible thanks to laser technology, leads to larger sensitivity, selectivity and precision, compared to lower resolution IR spectrometry such as in Fourier Transform InfraRed (FTIR) spectrometry. Line strengths in the mid infrared region $(2.5-25 \mu \mathrm{m})$ of absorbing atmospheric trace gases are known to be 2 or 3 orders of magnitude higher than in the Near Infra Red region $(0.8-2.5 \mu \mathrm{m})$. Quantum Cascade Lasers (QCLs) are more and more used in the mid infrared region because (i) they provide high and reproducible output power (several tens of mW), (ii) they can now operate at or near Room Temperature (RT), with small Peltier thermoelectric coolers replacing large cryogenic liquid $\mathrm{N}_{2}$ dewars (Beck et al., 2002), (iii) they present reproducible resonant modes, and (iv) they are tunable over large spectral windows $(\sim 10$ $\mathrm{cm}^{-1}$ ) giving versatility for the choice of the species to be measured. Moreover Distributed FeedBack (DFB) QCL, built with a grating inside the cavity, allow for exhibiting an excellent single-mode and a well-defined behaviour. In addition, Continuous Wave (CW) operating mode lasers provide better ease 
and higher precision for concentration retrieval, larger selectivity and sensitivity than pulsed mode operating lasers because of a reduced linewidth (Herndon et al., 2007).

Sensitivity from high resolution IR spectrometers are also obtained from a multiple reflection cell made of high reflectivity mirrors, which can behave as (i) a non resonant cavity as it is the case for the patented SPIRIT cell (Robert, 2007) or modified Herriott type cells (Nelson et al., 2004; Kosterev et al., 2000) or (ii) a resonant cavity (Fabry-Pérot type) as it is the case in Cavity Ring Down Spectroscopy (CRDS) (e.g., Picarro Inc., CA, USA) and in Cavity Enhanced Absorption Spectroscopy (CEAS) (Romanini et al., 2006, for $\mathrm{CH}_{4}$; Bertseva et al., 2002, for $\mathrm{N}_{2} \mathrm{O}$; Los Gatos Research Inc., CA, USA; Hendriks et al., 2008). By opposition to CRDS and CEAS, the non resonant multiple reflection cells provide shorter optical length paths and thus lower sensitivities but higher versatility as regard to the type and the concentration range of species to be measured in the atmosphere within the same cell because (i) the whole mid IR spectrum area can be used with the same type of mirrors (presenting an acceptable reflectivity over a larger band), and (ii) the optical path length can be varied, with a specific ease in the case of the patented SPIRIT cell.

SPIRIT is equipped with the best current laser technology, i.e. CW-DFB-RT-QCL, for measurement of atmospheric trace gases in general (present at or well below the ppb level) with high precision for concentration. For the more abundant species among them such as $\mathrm{CH}_{4}$ and $\mathrm{N}_{2} \mathrm{O}$, most instruments are equipped with pulsed wave DFB-RT-QCL and a Herriott type Cell, such as the QCLTILDAS-76 (Nelson et al., 2004; Kroon et al., 2007) model provided by Aerodyne Research Inc.® (ARI, USA) and another instrument developed by Kosterev et al., (2000) used for field studies (Wright, 2006). Some instruments have been recently modified to host CW-DFB-RT-QCLs, such as the ARI instrument (Neftel et al. 2010), because this QCL type is best to provide the required concentration precision at a $10 \mathrm{~Hz}$ sampling rate needed for flux measurements of $\mathrm{N}_{2} \mathrm{O}$ and $\mathrm{CH}_{4}$ using the Eddy Covariance method. MIR spectroscopy using CW-DFB-RT-QCLs and long path $(>200 \mathrm{~m})$ multipass cells have now demonstrated to provide a precision better than $0.1 \%$ on the volume mixing ratio of ambient air trace gases. Such precision is needed for flux emission and isotopic ratio measurements (McManus et al. 2010 and 2011).

\section{Instrument description and method for concentration retrieval}

SPIRIT is a transport wheel instrument $\left(\sim 100 \mathrm{~kg} ; 120 \times 80 \times 50 \mathrm{~cm}^{3}\right)$. It is supplied in the field by an electricity gasoline generator and can operate within less than $20 \mathrm{~min}$ after deployment. The principle of SPIRIT has been explained through the description of a laboratory prototype in Joly et al. (2008). Only the optical cell and the laser component of this prototype have been kept for building the new portable field instrument with better performances described hereafter. In particular, two 
measurement channels have been added, the electric current controller and temperature controller of the lasers, the data acquisition system, the detection system and the method for concentration retrieval have been redesigned, based on our experience on the balloon-borne instrument SPIRALE operating with six lead-salt diode lasers simultaneously, which we previously built (Moreau et al., 2005). The principle of the instrument is schematized in figure 1. The goal is to allow for SPIRIT future operation with three QCLs (i.e. measurement channels) while keeping the use of one optical cell and two detectors only - one for the measurement channel and the other one for the reference channel. Thanks to the home-made QCL emission controller, the lasers will work sequentially, triggered and synchronized by the data acquisition system. At present, only one DFB CW RT QCL laser (Alpes Laser) is operating one third of the time, for simultaneous detection of $\mathrm{N}_{2} \mathrm{O}$ and $\mathrm{CH}_{4}$. This laser produces a pure single mode radiation in the whole spectral range $1255-1265 \mathrm{~cm}^{-1}$ by a cooling between $+30^{\circ} \mathrm{C}$ and $-30^{\circ} \mathrm{C}$ with a Peltier thermoelectric cooler included in the QCL housing. A waterglycol circuit regulated at a constant temperature of $15^{\circ} \mathrm{C}$ is used for cooling the Peltier thermoelectric cooler. The laser emission window has been designed to be thermally decoupled from the Peltier thermoelectric cooler hosting the laser component by a 1-cm thick plastic material. Moreover the laser housing is under vacuum, and therefore condensation is avoided on the emission window. Mode purity has been checked by observing that null optical transmission from saturated lines of concentrated $\mathrm{CH}_{4}$ and the laser switching-off give equal electric signals. This single mode property leads to a simpler optical system, as shown in figure 2 and described below, without the need of another grating than the DFB one. Temperature and current settings are provided by feedback controllers driven by a numerical electronic module receiving commands from a laptop computer via a RS-232 interface. The micro-window used for the present study is $1261.87-1262.30 \mathrm{~cm}^{-1}$, selected by cooling the QCL at -9.0 ${ }^{\circ} \mathrm{C}$ and injecting a current of $290 \mathrm{~mA}$ with a saw-tooth ramp of $34 \mathrm{~mA}$ repeated at $244 \mathrm{~Hz}$, including a turn-around of $100 \mu \mathrm{s}$. The laser output power varies between about 20 and $27 \mathrm{~mW}$. The QCL housing includes an off-axis parabolic mirror of $5 \mathrm{~mm}$ focal length, mounted on the same Peltier-cooled copper mechanical support as the laser itself, in order to ensure optical alignment stability. The optical layout is presented in figure 2, with a ray traced for the presently single laser. The beam goes out from this housing through an anti-reflection coated $\mathrm{ZnSe}$ window, and is then divided in two parts by a beam splitter $\left(\mathrm{BaF}_{2}\right)$. One minor part $(\sim 4 \%)$ is reflected toward a home-made Fabry-Pérot etalon used as reference channel for relative spectral calibration. A location is anticipated for a small optical cell containing gaseous species with well-established spectra to be added on the path of this reference channel with the aim of absolute wavelength scale calibration. This reference beam is reflected on a flat mirror and focused onto a 250- $\mu \mathrm{m}$ photovoltaic HgCdTe detector (Judson 519D10) by a spherical mirror (140 mm radius). The other (major) part of the beam is directed and focused at the entrance of the optical cell after one reflection over a flat mirror, one reflection over a focusing spherical mirror (1000 mm radius) and two other ones by flat mirrors. The measurement output beam is collected by a 
flat mirror and focused onto a similar detector by a spherical mirror similar as the reference beam. Both detectors are cooled by a Stirling cycle cooler (Thalès Cryogénie RM2-7i/02) mounted in a home-made Dewar. Liquid nitrogen is therefore no more used to cool the detectors.

The detected electric signal is amplified, first by a preamplificator with a fixed gain and secondly, by an automatically self-adjusted gain in the main electronic module. A 16-bit analog-to-digital converter allows for detecting a theoretical minimum absorption of $1 / 2^{16}$, i.e. $\sim 1.5 \times 10^{-5}$. One hundred and ten measurement spectra followed by eight reference spectra are acquired and averaged. With the $244 \mathrm{~Hz}$ frequency, this gives a measurement period of $1.5 \mathrm{~s}$ per laser, including the data processing and the transfer to the laptop computer via a RS-232 interface. Contribution from the detector dark current is measured during the two thirds of every period during which the laser is switched off. As shown in figure 3, each scan is composed of 1024 points as a function of time, including about 850 useful points and the other ones containing the dark current level and the transient signal during laser thermalization to the required temperature. This gives the maximum spectral resolution, namely $5 \times 10^{-4} \mathrm{~cm}^{-1}$, depending on the micro-window $\left(\sim 0.43 \mathrm{~cm}^{-1}\right)$ swept by the laser.

The optical cell is a patented multiple-reflection cell (French patent 05/08396 and International patent WO 2007/017570 A1) detailed in a previous paper (Robert, 2007). In brief, it behaves as multiplier of a Herriott cell from which it inherits the excellent opto-mechanical stability, but it is much more compact. Its other main advantages are that it is made of three standard spherical mirrors with great mechanical tolerance, it is easily set up and tuned for adjusting the path length from 20 to $400 \mathrm{~m}$ by the rotation of only one mirror, and it allows the use of higher numerical aperture beams. In the configuration used for the present experiments, the total optical path length $L$ is $14040 \mathrm{~cm}$, thanks to 216 paths in a $65 \mathrm{~cm}$ long cell. One of the mirrors (the standing alone represented on the right of both figures 1 and 2$)$ is slowly and regularly moved by a piezoelectric actuator on a small range $(<100$ $\mu \mathrm{m})$ back and forth at $0.3 \mathrm{~Hz}$ frequency. By successive spectra averaging, this motion induces a reduction of unwanted fringes of interferences between the laser emission and the scattered light in the multi-reflection cell. The cell temperature is measured by a Pt100 resistance probe with a precision of $0.01 \mathrm{~K}$. Sampled air is continuously drawn via PFA Teflon tubes ( $6 \mathrm{~mm}$ o.d., $10 \mathrm{~m}$ lengh) through this cell using a scroll pump (XDS10 Boc Edwards), with a flow rate of about 3.0 STP L min ${ }^{-1}$ (Standard Temperature and Pressure: $\mathrm{T}=273.15 \mathrm{~K}, \mathrm{P}=1013.25 \mathrm{hPa}$ ). This leads to an effective flow rate of more than $1.2 \mathrm{~L} \mathrm{~s}^{-1}$ in the cell, maintained at a constant reduced pressure of about 30-40 $\mathrm{hPa}$, precisely known $( \pm 0.01 \mathrm{hPa})$ using a new gauge $(0-130 \mathrm{hPa}$ range, Scaime DL), by tuning a manually actuated dosing valve (EVN116 Pfeiffer Vacuum) located at the cell output, upstream of the pump. This pressure reduction enabled the $3.3 \mathrm{~L}$ cell content to be completely renewed in less than $3 \mathrm{~s}$. The low pressure also allows for the trace gas species ro-vibrational lines broadening to be reduced, so that the 
lines of different molecules are clearly distinguished and the baseline (i.e. the laser signal without absorption) is easily interpolated, which improves the measurement accuracy and the sensitivity.

The signal scans sampled as a function of time are converted into spectra as a function of wavenumber thanks to the Fabry-Perot etalon. This one generates interference fringes of $1.183 \times 10^{-2}$ $\mathrm{cm}^{-1}$ free spectral range, whose optimum positions are detected and fitted by a numerical spline interpolation. The baseline of the signals is deduced from a polynomial interpolation over the full spectrum. The transmission $T(\tilde{v})$ as a function of the wavenumber $\tilde{v}$ is finally retrieved by dividing the experimental signal by the associated baseline. The $\mathrm{N}_{2} \mathrm{O}$ and $\mathrm{CH}_{4}$ ro-vibrational lines used in the present study are positioned at the central wavenumbers $\tilde{v}_{0} 1261.9874$ and $1262.2285 \mathrm{~cm}^{-1}$, with line intensities $S_{(T)}$ of $1.044 \times 10^{-19}$ and $2.723 \times 10^{-20} \mathrm{~cm}$ molecule ${ }^{-1}$ at $T=296 \mathrm{~K}$, respectively (Rothman et al., 2009). The concentration retrieval is based on the Beer-Lambert law,

$$
C=\frac{-\ln [T(\tilde{v})]}{S_{(T) \cdot} \cdot g\left(\tilde{v}-\tilde{v}_{0}\right) \cdot L}
$$

where $C$ is the molecular concentration (molecules $\left.\mathrm{cm}^{-3}\right), g\left(\tilde{v}-\tilde{v}_{0}\right)$ is the absorption profile $(\mathrm{cm})$, and $L$ is the path length $(\mathrm{cm})$. The principle of the retrieval is to fit the experimental optical depth, $\ln [T(\tilde{v})]$, to the simulated one, C.S $S_{(T)} g\left(\tilde{v}-\tilde{v}_{0}\right) . L$, by adjusting the concentration C. The fitting is performed by using a linear least-square algorithm. The intensity $S_{(T)}$ includes the molecular partition functions and the lower-state energy of the transition $E$ ”. $g\left(\tilde{v}-\tilde{v}_{0}\right)$ is assumed to be a Voigt profile involving a Doppler (Gaussian) profile and a collisional (Lorentzian) profile parameterized by the air broadened half-width $\gamma_{a i r}$ and its temperature-dependence exponent $n_{\text {air }}$ calculated from the Hitran 2008 database (Rothman et al., 2009). The key advantage of the CW QCLs with respect to lead-salt diode lasers and pulsed QCLs is the better spectral quality, with a linewidth negligible (determined in the present study to have a HWHM $<1.5 \times 10^{-4} \mathrm{~cm}^{-1}$ ) with respect to the collisional and Doppler broadenings of the molecular line under the actual field pressure and temperature conditions. Thus, the laser linewidth does not need to be accounted for in the experimental absorption profile, which suppresses a systematic error source. Figures 4 (a) and (b) show an example of a transmission spectrum and the associated residual, i.e. the difference between the experimental and the simulated transmission spectra. Baseline signal variations of several origins (e.g., fringes of interferences between the laser emission and the scattered light from optical components with various free spectral ranges, fluctuations of the laser background emission signal, beam wandering on the detector surface) may complicate the retrievals with the direct absorption line fitting method in some cases, because the zero absorption signal is difficult to reconstruct. Another retrieval method consists of applying a numerical derivative that efficiently removes the continuous component of the signal, as already used 
and validated in the case of SPIRALE balloon-borne instrument (for more details see Moreau et al., 2005). The second derivative method is preferred, compared to the direct absorption method, because it transforms absorption lines into symmetrical signatures, which are easier to handle, and reduces the fringes efficiently, which is most useful for species with very low line strengths or in low abundances. Statistical noise is usually smaller in the second derivative due to the associated filtering. This method, illustrated in figures 4 (c)-(d), has been proven to be very useful, leading to accurate data for chemistry and dynamics studies of the lower stratosphere (see e.g., Berthet et al., 2006; Huret et al., 2006; Berthet et al., 2007; Müller et al., 2007; Pirre et al., 2008; Mébarki et al., 2010) as well as for validation of satellite instruments such as Envisat MIPAS and GOMOS, ACE-SCISAT FTS, Odin SMR and Aura-MLS (see e.g., Wang et al., 2007; Renard et al., 2008; Strong et al., 2008; Jégou et al., 2008; Mébarki et al., 2010). In the case of high absorptions such as for $\mathrm{CH}_{4}$ or $\mathrm{N}_{2} \mathrm{O}$ species, both methods lead to the same results and precisions (as shown in figure 4).

The overall uncertainties on the volume mixing ratios have been assessed by taking into account random errors and systematic errors. Sources of random error include the signal variations quoted above and other statistical noise. The theoretical detection limit of $\sim 1.5 \times 10^{-5}$ in absorption is not achieved, due to these random errors of about $1 \times 10^{-4}$ magnitude, as observed as different frequency oscillations in figure 4 (b). For highly absorbing and/or abundant species such as $\mathrm{N}_{2} \mathrm{O}$ or $\mathrm{CH}_{4}$, i.e. absorbing by more than $5 \times 10^{-2}$ under ambient atmospheric conditions, a $10^{-4}$ precision in absorption leads to a precision of about $0.2 \%$ in volume mixing ratio, namely $\sim 0.6 \mathrm{ppb}$ for $\mathrm{N}_{2} \mathrm{O}$ and $\sim 4$ ppb for $\mathrm{CH}_{4}$. This is confirmed by the calculations of $1 \sigma$ uncertainties for measurement series of at least 10 data $(15 \mathrm{~s})$, giving a precision of about $0.2 \%$. This precision is considered as the sensitivity to concentration variations and also approximately as the detection limit for field measurement realistic times. In order to evaluate the SPIRIT performances in terms of time dependence precision and possible drift behaviour, the Allan variance has been calculated, as it is usually the case for on-line laser instruments (see e.g., Werle et al., 1993; Fried et al., 1998, Nelson et al., 2004; Joly et al., 2008; Skrinsky et al., 2009, Neftel et al., 2010, Tuzson et al., 2010). The log-log plot of Allan variance versus integration time shows a linear decay out to about $250 \mathrm{~s}$, as shown for $\mathrm{N}_{2} \mathrm{O}$ in figure 5 as an example. This time corresponds to a minimum standard deviation $\sigma_{\text {Allan }}$ of $0.13 \mathrm{ppb}$ for $\mathrm{N}_{2} \mathrm{O}(0.040 \%)$ and $0.62 \mathrm{ppb}$ for $\mathrm{CH}_{4}(0.031 \%)$. This minimum describes the turn-over point where the white noise becomes dominated by additional drift noise, likely due to changes in optical alignment. This theoretical maximum precision could therefore be reached within this integration time $(\sim 4 \mathrm{~min})$ and lasts about $1 \mathrm{~h}$. These results are of great improvement compared to those of our previous laboratory prototype (Joly et al., 2008) where the variance minimum was attained at $1280 \mathrm{~s}(\sim 21 \mathrm{~min})$ for a few minutes and with a higher minimum $\sigma_{\text {Allan }}$ of $0.5 \mathrm{ppb}$ for $\mathrm{N}_{2} \mathrm{O}$ and $3 \mathrm{ppb}$ for $\mathrm{CH}_{4}$ at ambient air concentrations. The main reasons are believed to be the new current and temperature controllers of the 
lasers, the new data acquisition system and the new pressure gauge. These SPIRIT's standard deviations $\sigma_{\text {Allan }}$ were obtained from laboratory room air non constant volume mixing ratios. Similar performances were obtained with ambient air in the field with shorter time integration $(<30 \mathrm{~min})$. These performances can be considered as conservative estimates because Allan variance is best determined on samples from gas cylinders with constant mixing ratios.

SPIRIT exhibits performances similar to (i) the ARI QCL spectrometer for $\mathrm{N}_{2} \mathrm{O}: \sigma_{\text {Allan }}$ of $0.12 \mathrm{ppb}(1$ $\mathrm{Hz}$ ), reached after $200 \mathrm{~s}$ averaging time (Neftel et al., 2010), and for $\mathrm{CH}_{4}: \sigma_{\text {Allan }}$ of $0.23 \mathrm{ppb}(1 \mathrm{~Hz})$, reached after $500 \mathrm{~s}$ averaging time (Tuzson et al., 2010), and to (ii) the LGR Fast Methane (FMA) Analyser for $\mathrm{CH}_{4}$ : $\sigma_{\text {allan }}$ of $0.58 \mathrm{ppb}(1 \mathrm{~Hz})$, reached after $500 \mathrm{~s}$ averaging time (Tuzson et al., 2010).

Concerning potential systematic errors, they include the retrieval process, the spectroscopic parameters and the non-linearity of the detector response. The latter has been checked to be better than $0.5 \%$. The most important potential systematic uncertainties originate from the spectroscopic data. The spectral micro-window can be chosen so that the Hitran spectroscopic parameters are more accurate than $5 \%$ (Rothman et al., 2009). A 5\% uncertainty on the molecular line intensity $S_{(T)}$ proportionally propagates in the concentration value uncertainty. The field temperature is close to the reference temperature of Hitran database (296 K) so that the uncertainties on the temperature dependencies of $S_{(T)}$ (determined by the partition functions and $E$ ") and the air-broadened coefficient $\gamma_{\text {air }}$ (determined by $n_{\text {air }}$ ) are negligible. Therefore, the only other important spectroscopic parameter to consider for the uncertainty evaluation is $\gamma_{\text {air }}$ at ground ambient temperature, primarily defining the line shape. The impact of its uncertainty has been evaluated in the concentration retrieval process by a sensitivity analysis using the fitting software. A $5 \%$ variation of $\gamma_{\text {air }}$ results in an uncertainty of $2.5 \%$ for the concentration. Finally, the precision on the retrieval, illustrated in figures 4 (b) and (d) for $\mathrm{CH}_{4}$, is essentially limited by this $\gamma_{\text {air }}$ accuracy. In addition, concentration retrieval is found to be affected by line broadening effect linked to the air water vapour content as described by Neftel et al. (2010). Water vapour enrichment during field studies is significant enough to affect the gas matrix composition. Our current retrieval algorithm is parameterized with the HITRAN database "dry" airbroadened half-width $\gamma_{\text {dry air }}$ only, so without taking into account the species line broadening by water vapour. Instrument response to rapid changes in water vapour mixing ratio content has been quantified from chamber experiments, within the range of 0.5 to $3 \%$ representative from field conditions, leading to an apparent decrease of $\mathrm{N}_{2} \mathrm{O}$ and $\mathrm{CH}_{4}$ mixing ratios of $1 \%$ and $0.5 \%$ at most, respectively, after correction from volumetric dilution by the water vapour. This decrease is observed only above $1 \%$ water vapour mixing ratio. One can note that by opposition to the EC (Eddy Covariance) method for flux measurement as used in Neftel et al. (2010), air line broadening correction do not affect significantly derived fluxes from chamber experiments and are usually not taken into account unless very small fluxes need to be quantified. 
The sensitivity analysis has been also applied to the other essential parameters influencing the retrieval, i.e. pressure and temperature. Uncertainties of $0.2 \mathrm{hPa}$ and $0.5 \mathrm{~K}$ have been found to influence the accuracy of the molecular concentration by $0.3 \%$ and $0.15 \%$, respectively. Sensitivity to the outside temperature fluctuations on the retrieval process has also been quantified. Outside temperature fluctuations may induce a slight misalignment of the optical elements, which in turn induces a decrease of the signal intensity received on the detector. This does not significantly $(<1 \%)$ change the species volume mixing ratios measured in the ambient air, having in mind that this changes may also come from the natural ambient air variations. For instance, the same values of $\mathrm{N}_{2} \mathrm{O}$ ambient air volume mixing ratio (within $1 \%$ ) were measured within $25^{\circ} \mathrm{C}$ outside temperature variation in the La Guette peatland (see section 4.1.2. for more details on these field experiments) over a $20 \mathrm{~h}$ experiment duration. $\mathrm{N}_{2} \mathrm{O}$ ambient air volume mixing ratio was considered to remain constant because La Guette peatland was not observed to be a $\mathrm{N}_{2} \mathrm{O}$ surface emitter.

As a conclusion, the overall uncertainty on the volume mixing ratio, calculated as the square root of the quadratic sum of the random and the systematic uncertainties, is estimated to be around $3 \%$ (under dry conditions) without taking into account the potential systematic uncertainty of $5 \%$ on the line intensity $\mathrm{S}$ (or about $6 \%$ with the later contribution).

Intercomparisons have been performed between volume mixing ratios obtained from Gas phase Chromatography (GC) and standard pressurized cylinders vs our infrared spectrometer (SPIRIT), over a concentration range representative from flux field measurements. $\mathrm{N}_{2} \mathrm{O}$ and $\mathrm{CH}_{4}$ mixture glass bulbs were used, one filled with ambient air $\left(\mathrm{N}_{2} \mathrm{O}: 325 \mathrm{ppb}\right.$ and $\left.\mathrm{CH}_{4}: 1990 \mathrm{ppb}\right)$ and two others filled with $\mathrm{N}_{2} \mathrm{O} / \mathrm{CH}_{4}$ doped dry air (bulb 1: 1.208 ppm $\mathrm{N}_{2} \mathrm{O}$ and 4.980 ppm $\mathrm{CH}_{4}$; bulb 2: $6.028 \mathrm{ppm} \mathrm{N}_{2} \mathrm{O}$ and $10.17 \mathrm{ppm} \mathrm{CH}_{4}$ ). These volume mixing ratio values derived from SPIRIT were prepared from multiple dilution steps in a vacuum system using certified Baratron ${ }^{\circledR}$ pressure gauges and pure pressurized $\mathrm{N}_{2} \mathrm{O}$ and $\mathrm{CH}_{4}$ cylinders. $\mathrm{N}_{2} \mathrm{O}$ and $\mathrm{CH}_{4}$ were sampled from the bulbs via a $6 \mathrm{~mm}$ o.d. PFA Teflon line in which a T Swagelok holds a septum for simultaneous sampling from gas-syringes in order to perform off line GC analysis. Simultaneously with SPIRIT measurements, and for each bulb, four gas samples of $20 \mathrm{~mL}$ were injected into $12-\mathrm{mL}$ glass vials sealed with a rubber septum and a silicone septum (Exetainers ${ }^{\circledR}$, Labco, High Wycombe, UK). Tubes were stored under ambient conditions for less than a month and then analyzed using a gas chromatograph (Model 3800, Varian Inc., Walnut Creek, CA) equipped with ECD $\left(\mathrm{N}_{2} \mathrm{O}\right)$ and FID $\left(\mathrm{CH}_{4}\right)$ detectors, according to the protocols described in Rochette and Bertrand (2007). Figure 6 a shows that GC data scattering ( $Y$ axis) are significantly larger than SPIRIT data (X axis) for $\mathrm{N}_{2} \mathrm{O}$. This $\mathrm{Y}$ axis scattering is better shown on figure $6 \mathrm{~b}$ where the averaged volume mixing ratios measured for $\mathrm{N}_{2} \mathrm{O}$ by GC were $(2.7 \pm 3.1 \%, 1 \sigma$ precision) higher than the ones measured by SPIRIT $(0.2 \%, 1 \sigma$ precision). SPIRIT's precision and accuracy have also been checked from two $\mathrm{N}_{2} \mathrm{O}$ standards independently prepared from Air Liquide ${ }^{\circledR}$ in dry $\mathrm{N}_{2}$ pressurized cylinders 
demonstrating good agreement and reproducibility of SPIRIT values over a 6 months period time (figure $6 \mathrm{~b}$ ). The volume mixing ratio values derived from SPIRIT agree within $2 \%$ with the ones calculated from multiple dilution steps in bulbs and provided from pressurized $\mathrm{N}_{2} \mathrm{O}$ standard cylinders. GC data for $\mathrm{CH}_{4}$, not presented here, showed lower values $(-6.7 \pm 3.5 \%, 1 \sigma$ precision), which are also confirmed from bulbs and a certified pressurized 2 ppm (1\% precision) cylinder from Air Liquide ${ }^{\circledR}$. The reproducibility of the $\mathrm{N}_{2} \mathrm{O}$ and $\mathrm{CH}_{4}$ mixing ratios values measured in the laboratory ambient air and during the several field campaigns has also been shown to be very good (variations $<2-3 \%$ : $323 \pm 8 \mathrm{ppb}$ and $1.90 \pm 0.05 \mathrm{ppm}$ ), over 30 months period from August 2008 to February 2011.

To summarize, SPIRIT data are accurate by $6 \%$ due to non accurate spectroscopic parameters (line strength and shape) and this accuracy can be reduced to 3\% when more accurate spectroscopic parameters will be released in the Hitran database. Correction for water vapour presence should be taken into account in the presence of more than $1 \%$ of this species. According to the volume mixing ratio overall uncertainties given by SPIRIT for $\mathrm{N}_{2} \mathrm{O}$ and $\mathrm{CH}_{4}(6 \%, 1 \sigma)$, by GC-ECD for $\mathrm{N}_{2} \mathrm{O}(3 \%, 1 \sigma)$ and by GC-FID for $\mathrm{CH}_{4}(1 \%, 1 \sigma)$ (Rochette and Bertrand, 2007), data are within the accuracy range of the measurements obtained by the two analytical methods. Despite the good accuracy claimed by GC, the off line GC protocol is shown to be less precise than the online SPIRIT infra red spectrometry for volume mixing ratio retrieval as shown in figure 6 .

\section{Methodology for flux retrieval}

\subsection{Rationale for the use of a closed chamber method}

Two main methods for flux measurements of gases at the soil-atmosphere interface are available (Guenther et al., 1996; Laville et al., 1997). The first ones are chamber methods that are put at the soil surface during the measurement period, usually varying from several to twenty minutes. The flux is derived either (i) from the rate of accumulation of the gas concentration as a function of time for the closed chambers, or (ii) from the gas concentration difference between the inside of the chamber and the ambient air for the open chambers. The second ones are micrometeorological methods: (i) the gradient method (diffusive transport predominating) consists in calculating fluxes from both vertical profiles of gas concentration and horizontal mean wind speed in the first few meters above the surface, (ii) the Eddy Covariance (EC) method (turbulence transport predominating) consists in calculating the vertical flux by the mean product of a gas concentration $c$ and the vertical wind velocity $w$ sampled in one location at high frequency $(10 \mathrm{~Hz})$, the time lag between the air sampling and analysis being determined as that giving the maximum correlation coefficient between $w$ and $c$.

It is now well established that the chamber method remains the best technique to assess spatial variability of emissions and also if a detailed process-oriented study of flux emissions needs to be achieved at the scale of the vegetation type $\left(1 \mathrm{~m}^{2}\right)$ such as in peatlands (Hendriks et al., 2010). In 
peatlands, strong space and time variations for $\mathrm{CH}_{4}$ emissions do exist and emissions often need to be studied as a function of biotic (e.g. vegetation, microbiology) or abiotic (e.g. soil temperature, $\mathrm{pH}$, humidity) parameters with the aim to investigate biogeochemical processes involved in the $\mathrm{C}$ cycles. EC is known to be the best method for assessing time variability of emissions at an upper scale (100 $\mathrm{m}^{2}$ ) (Hendriks et al., 2010) and is mainly appropriate if a uniform distribution of the emission sources does exist (such as for $\mathrm{N}_{2} \mathrm{O}$ in a homogenous cultivated field). It has also been shown that soil gradient method for $\mathrm{CH}_{4}$ emission from peatlands should be use with care and the results are likely reliable only in areas with low water table and shallow roots. According to the strong space variability of the emissions from the ecosystem studied here, to the frequent changes of emissions pathways (diffusive versus sudden strong bubbling events) for some plots of peatlands and water bodies, and to the microscale objectives of our investigations, chamber methods, described hereafter, were used. As a consequence, the current frequency of SPIRIT for concentration measurement $(0.67 \mathrm{~Hz})$ is needed to assess possible chambers artefacts and emissions pathways despite fluxes are inferred from an accumulation period in the order of minutes. More specifically the dynamic closed chamber method is used, meaning that the optical cell of SPIRIT is connected to the chamber via a PFA Teflon tubes where the headspace chamber air is sampled from and re-injected to the chamber (before and during enclosure) and passing through the SPIRIT optical cell. A sufficient sampled volume rate ( 3 STP L $\left.\min ^{-1}\right)$ is maintained in order to keep a short delay between sampling and analysis, but low enough to avoid a pressure gradient inside the chamber when enclosed.

\subsection{Experimental conditions for the derivation of a flux using the closed chamber method}

The flux of $\mathrm{CH}_{4}$ or $\mathrm{N}_{2} \mathrm{O}$ (named $i$ ) per surface unit $\mathrm{F}^{\mathrm{S}} i$ (molecule $\mathrm{m}^{-2} \mathrm{~s}^{-1}$ ) is inferred from the slope of the stabilized linear increase of the i volume mixing ratio $X_{i}$ with time (from a 3 to 10 minutes period usually) starting from the observable linear increase after enclosure and is given by Eq. (2),

$$
F^{S}{ }_{i}=\frac{P}{k_{B} \cdot T} \cdot h \cdot \frac{d X_{i}}{d t}
$$

where $P$ is the pressure in the chamber $(\mathrm{Pa}), k_{B}$ the Boltzmann constant $\left(1.381 \times 10^{-23} \mathrm{~J} \mathrm{~K}^{-1}\right), T$ the absolute temperature $(\mathrm{K}), h$ the mean height of the chamber above the soil surface $(\mathrm{m})$ or more precisely, the volume of the closed loop (reduced to the chamber pressure) to the surface ratio of the soil emitter, $X_{i}$ the volume mixing ratio of $i$ in the chamber (unit-less), $d X_{i} / d t$ the rate of accumulation of $i$ in the chamber $\left(\mathrm{s}^{-1}\right)$. Many kinds of units are given to express fluxes of gases according (i) to the field of investigations, such as atmospheric sciences, agronomy, biology, global geochemical cycles models using mass balances of exchanges, and (ii) to the time and space scales where the fluxes are 
considered, which depend mainly on their existing time and space stabilities in the considered ecosystem. $\mathrm{F}^{\mathrm{S}} \mathrm{i}$ can also be given by Eq. (3) using practical units:

$$
F_{i}^{S}=A \cdot \frac{P}{T} \cdot h \cdot \frac{d X_{i}^{\prime}}{d t}
$$

where the $A$ constant value provides the desired unit for the $\mathrm{F}^{\mathrm{S}} i$, as given in Table 1; $P$ is given in $\mathrm{hPa}$, $T$ in $\mathrm{K}, \mathrm{h}$ in $\mathrm{cm}$, and $d X_{i}^{\prime} / d t$ in parts per billion per second $\left(\mathrm{ppb} \mathrm{s}^{-1}\right)$.

To derive the flux, the slope $d X_{i} / d t$ of the gas mixing ratio curve is calculated using the linear regression method because according to the short integration period usually used (6 minutes) no significant difference is observed between the linear regression method, the slope intercept method and the exponential regression method (see Kroon et al., 2008, for accurate derivation methods of fluxes). This approach is used to derive $\mathrm{CH}_{4}$ flux emission from peatlands (Schrier-Uijl et al., 2010). However SPIRIT instrument time resolution $(1.5 \mathrm{~s})$ for the online concentration measurement provides a much more precise monitoring of $d X_{i} / d t$ compared to the work from Schrier-Uijl et al. (2010) in which $d X_{i} / d t$ is derived from an integration period of 5 minutes based on a 5 concentration data points after enclosure of the chamber, using a photo acoustic gas monitor with a limited time resolution (1 $\min )$.

For flux measurements in peatlands and water bodies a large volume plexiglass transparent chamber (height $=29 \mathrm{~cm}$, internal diameter $=30 \mathrm{~cm}$, volume $=20.5 \mathrm{~L}$ ) is used due to the size of some vegetation present in peatlands (Betula spp or Molinia caerulea). A small fan is installed on top of the chamber to homogenize the inside air, as recommended for high chambers, which otherwise could be affected by poor air mixing (Rochette and Eriksen-Hamel, 2008). To insure reliability and high quality of each flux measured with the closed chamber, all tests (i.e. headspace chamber air ventilation and flow rate sampling) recommended by Davidson et al. (2002) were performed for all kinds of emitting surfaces and all the criteria given by Rochette and Eriksen-Hamel (2008) were also taken into account.

All chosen peatland slots where gas emissions are measured are equipped with a permanent PVC cylinder collar (internal diameter $=30 \mathrm{~cm}$ ) sunk into the soil (at approximately $10 \mathrm{~cm}$ below the water surface). The top of the emerging part of the collar is levelled to the top of the sphagnum cuspidatum, leading to a typical mean height chamber of $45 \mathrm{~cm}$. The seal between the inside and the outside air is ensured by the weight of the chamber fitted on the top of the collar by the mean of a wetted silicon oring sealed on the chamber.

Care was taken to avoid known chamber artefacts as described by Davidson et al. (2002) which may affect significantly the natural emission such as (i) pressure changes during chamber enclosure, (ii) inside and outside chamber pressures drift during accumulation, or (iii) alteration of the natural concentration gradient within the soil (or within the water table) due to the concentration rise in the 
headspace of the chamber. To avoid these respective artefacts, (i) the top of the chamber is connected to a short $4 \mathrm{~mm}$ outlet exit line open to the outside air and closed few seconds after enclosure, (ii) the pressures inside and outside the chamber are continuously checked during accumulation with a manometer (the stability of pressures and the pressure differential are kept below $0.1 \mathrm{hPa}$ thanks to a vent located on top of the chamber as recommended by Davidson et al. (2002) and Hutchinson and Livingston (2001)), and (iii) the flux measurement integration period is short and usually takes into account the first 6 minutes after enclosure. For flux measurements from water bodies, such as the Loire river or the Pavin volcanic lake, the same chamber is used, fitted to a similar PVC collar partially sunk inside the water and stabilized by a floating belt.

\subsection{Precision and accuracy for fluxes}

The flux detection limit for $\mathrm{N}_{2} \mathrm{O}$ and $\mathrm{CH}_{4}$ emission is calculated for a 6 minutes accumulation rate using the two standard deviations of $1.2 \mathrm{ppb}$ and of $8 \mathrm{ppb}$ obtained for the sensitivity to the concentration variation of $\mathrm{N}_{2} \mathrm{O}$ and $\mathrm{CH}_{4}$, leading then to a rate of accumulation detection limit for $\mathrm{N}_{2} \mathrm{O}$ and $\mathrm{CH}_{4}$ of $3.3 \times 10^{-3} \mathrm{ppb} \mathrm{s}^{-1}$ and $2.2 \times 10^{-2} \mathrm{ppb} \mathrm{s}^{-1}$, respectively (corresponding also to the minimum observable positive slope for $d X_{i} / d t$ ). Assuming a pressure of $1013 \mathrm{hPa}$, an absolute temperature of $298 \mathrm{~K}$, a maximum mean height of the chamber above the soil surface of $45 \mathrm{~cm}$ (for peatlands), the upper calculated/measured flux detection limit for $\mathrm{N}_{2} \mathrm{O}$ and $\mathrm{CH}_{4}$, expressed in usable units for atmospheric sciences, are $3.7 \times 10^{9}$ molecule $\mathrm{cm}^{-2} \mathrm{~s}^{-1}\left(6.1 \times 10^{-2} \mathrm{nmol} \mathrm{m}^{-2} \mathrm{~s}^{-1}\right)$ and $2.5 \times 10^{10}$ molecule $\mathrm{cm}^{-2}$ $\mathrm{s}^{-1}\left(4.1 \times 10^{-1} \mathrm{nmol} \mathrm{m}^{-2} \mathrm{~s}^{-1}\right)$, respectively; or, when expressed in units found in agronomic, biologic or

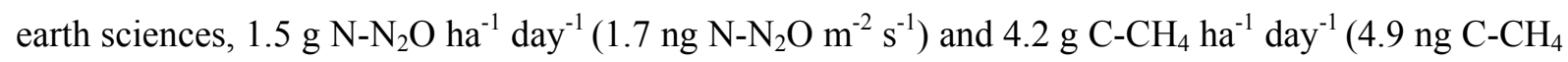
$\left.\mathrm{m}^{-2} \mathrm{~s}^{-1}\right)$ for our $45 \mathrm{~cm}$ high chamber .

The precision for $\mathrm{N}_{2} \mathrm{O}$ and $\mathrm{CH}_{4}$ for an individual measured flux, mainly given by the precision on the slope during linear increase of $\mathrm{N}_{2} \mathrm{O}$ and $\mathrm{CH}_{4}$, is better than $1 \%$ above 10 times flux detection limits. The overall uncertainty for an individual measured flux reach at most $10 \%$, mainly given from (i) the uncertainty of the mean height of the chamber (3 to $8 \%$ ) explained by the non homogenous ground surface due to the presence of the vegetation in case of peatlands, and from (ii) the overall uncertainty of the volume mixing ratio of $\mathrm{N}_{2} \mathrm{O}$ and $\mathrm{CH}_{4}(<6 \%)$.

\section{In situ measurements of $\mathrm{N}_{2} \mathrm{O}$ and $\mathrm{CH}_{4}$ fluxes in different ecosystems}




\section{1. $\mathrm{CH}_{4}$ from peatlands}

4.1.1. The research project. The world's peatlands influence the global carbon (C) cycle. In their natural state, peatlands have a cooling effect by sequestering and storing huge amounts of atmospheric $\mathrm{CO}_{2}$ via peat accumulation, and emit $\mathrm{CH}_{4}$. Peatlands are the only ecosystem that have stored in the last thousands years a $\mathrm{C}$ stock comparable to the total C present in the atmosphere (Falkowski et al., 2000). Northern Sphagnum dominated peatlands contain 20-30\% of the world's soil C stock (Gorham, 1991) and have the greatest peat accumulation potential due to low rates of plant residue decomposition (Thormann et al., 1999). However, strong uncertainties remain on their response to climate change or to anthropogenic perturbations as regard to net carbon exchanges with the atmosphere. The main reason is that the associated response of the global C cycle is still not understood (Belyea and Malmer, 2004). Human activities (drainage, fertilisation, peat extraction) and climate change (temperature increase, drought) expose large stocks of $\mathrm{C}$ to less constrained decomposition conditions. Thus peatlands may become significant sources of $\mathrm{CO}_{2}$ and at the same time do not totally stop to emit $\mathrm{CH}_{4}$, particularly in sub-arctic areas. Drained peatlands, especially after fertilization, can also become an important source of $\mathrm{N}_{2} \mathrm{O}$. A selected peatland has been chosen to investigate the effect of anthropogenic perturbations on biodiversity changes over time and on net carbon exchanges. The site is the La Guette peatland, a Sphagnum-dominated acidic fen located in the centre of France (Neuvy sur Barangeon, Cher; see Gogo et al., 2010a, for a detailed description of the site). The increased invasion of this peatland in the last decades by native vascular plants (Betula spp and Molinia caerulea) is due to a set of interacting causes, which comprise drainage by pine trees planted overslope of the peatland, water works probably affecting the water regime, changes in land-use (decreasing ecosystem renewing and increasing forest influence) and increasing nutrient input. As a result faster decaying litter may increase $\mathrm{CO}_{2}$ release without necessarily decrease $\mathrm{CH}_{4}$ emissions.

4.1.2. Field measurements. A first measurement campaign was conducted in La Guette's peatland on March 19, 2009. Space and time distributions of $\mathrm{CH}_{4}$ emissions as well as efflux pathway (diffusion transport versus bubbling events) were studied, thanks to the high time resolution of SPIRIT. No significant $\mathrm{N}_{2} \mathrm{O}$ emission was observed in that site. Figure 7 shows the two efflux pathways. Diffusive emission is the main process of $\mathrm{CH}_{4}$ emission. It is observed as a linear increase of $\mathrm{CH}_{4}$ concentration as a function of time resulting in a constant emission flux during the 10 minutes of $\mathrm{CH}_{4}$ accumulation, as observed in figure 7 for the Sphagnum cuspidatum part of the plot. For flux derivation when only diffusive emission occurs, $d X_{i} / d t$ is calculated using the linear regression method. The increase of $\mathrm{CH}_{4}$ concentration is sometimes broken by a sharp rise corresponding to a bubble event, as represented by the arrows in figure 7 for the Eriophorum vaginatum part of the plot. Due to the large increase of $\mathrm{CH}_{4}$ concentration inside the headspace of the chamber during bubble events, inhibition of the diffusive flux may be observed by the attenuation of $d X_{i} / d t$ over time for long accumulation period (20 minutes) 
as visually observable in this Eriophorum vaginatum part of the plot. Exponential regression method may be used to derive more accurately the diffusive flux. Table 2 shows that $\mathrm{CH}_{4}$ diffusive emissions ranged from $0.29 \mathrm{mg} \mathrm{CH}_{4}-\mathrm{C} \mathrm{m}^{-2} \mathrm{~h}^{-1}$ to $1.71 \mathrm{mg} \mathrm{CH}_{4}-\mathrm{C} \mathrm{m}^{-2} \mathrm{~h}^{-1}\left(70-410 \mathrm{~g} \mathrm{CH}_{4}-\mathrm{C} \mathrm{ha}^{-1} \mathrm{~J}^{-1}\right)$ during that day for the 4 types of vegetation. These values, as well as emissions processes, are commented in details in Gogo et al. (2010b). These values are in the range of previously published data and agree with the plant community where $\mathrm{CH}_{4}$ is the most produced and emitted in the wettest area. A second measurement campaign was conducted in La Guette's peatland on May 26 and 27, 2009 to get a better knowledge of the $\mathrm{CH}_{4}$ dependence emission with vegetation. Four vegetation species (addition of Molinia caerulea plots) in four different zones of the peatland were studied. Higher emissions occur for all vegetations compared to March 19 due to the temperature rise of the water layer $\left(14^{\circ} \mathrm{C}\right)$ responsible for the stronger micro-biological activities than in March. Gogo et al. (submitted, 2010c) demonstrated the importance of the interaction between vegetation and microbiological activities in the $\mathrm{CH}_{4}$ production. Under conditions of high photosynthesis activities, $\mathrm{CH}_{4}$ emissions become correlated to the soil temperature mainly for vascular plants, Molinia caerulea and Betula spp. Through their root, exudates vascular plants inject high enough labile carbon to allow for an increase of the microbial activity correlated with temperature, which is more intense for methanogens than for methanotrophs.

\section{2. $\mathrm{N}_{2} \mathrm{O}$ from fertilized soils}

4.2.1. The research project. Crutzen et al. (2008) pointed out that the amount of nitrous oxide emitted by agricultural nitrate fertilizers has been seriously underestimated. $\mathrm{N}_{2} \mathrm{O}$ emission predictions over different time and regional scales are very difficult to asses because relationships between soil properties, cultivated vegetation species, biotic and abiotic factors and emission magnitude are poorly understood. It is now established that $\mathrm{N}_{2} \mathrm{O}$ is mostly formed in soil through the microbial processes of nitrification and denitrification (Firestone and Davidson, 1989; Granli and Bøckman, 1994). These processes are controlled by several soil variables, such as the availability of mineral nitrogen $\left(\mathrm{NH}_{4}{ }^{+}\right.$ and $\mathrm{NO}_{3}{ }^{-}$), aeration, temperature, organic/labile carbon content (for denitrification) and $\mathrm{pH}$ (Firestone and Davidson, 1989; Davidson et al., 2000). $\mathrm{N}_{2} \mathrm{O}$ emissions from cultivated field are known to increase with inputs of $\mathrm{N}$ in form of mineral fertilizers and organic manure, and with humidity such as anoxic soils. $\mathrm{CH}_{4}$ may also be released if the anoxia is well pronounced. In order to asses (i) the $\mathrm{N}_{2} \mathrm{O}$ emissions budget from cultivated ecosystems and (ii) the reduction efficiency of $\mathrm{N}_{2} \mathrm{O}$ emissions by improving agricultural practices according to the Intergovernmental Panel on Climate Change (IPPC 2007), a pilot site is studied at a regional scale near Villebon (Beauce Chartraine and Faux Perche). This site has been chosen because a large spatial distribution of soil properties, humidity conditions, 
agriculture kinds and practices, does exist in this $10 \mathrm{~km}^{2}$ small territory. Field studies have started in spring 2010 during crop growth and fertilization.

4.2.2. $\mathrm{N}_{2} \mathrm{O}$ emission tests at INRA-Orléans. $\mathrm{N}_{2} \mathrm{O}$ emission tests have been performed on the field of INRA-Orléans to prepare the future campaigns on the site of Villebon. For those $\mathrm{N}_{2} \mathrm{O}$ specific flux measurements, the closed chambers are made of a disk dark lid fitted on a PVC or on a stainless steal collar (internal diameter $=47-49 \mathrm{~cm}$; height $=7.5 \mathrm{~cm}$ ) as described in Hénault et al $(2005)$. The chambers are sealed with foam rubber compressed with grips. Three parcels have been prepared in order to test strong different level of possible emissions. The soil is sandy (76.5\% of sand) and treatment before first measurements (September 26, 2008) are described on Table 3. The unfertilized soil is the reference parcel. Parcels 1 and 2 had input of organic carbon (horse manure was incorporated on $25 \mathrm{~cm}$ depth) and nitrogen $\left(\mathrm{NH}_{4} \mathrm{NO}_{3}\right)$ fertilizers. Soil was compacted with a tractor to obtain a high bulk density in the superficial layer $\left(1.62 \pm 0.05 \mathrm{Mg} \mathrm{m}^{-3}\right)$. In order to increase artificially $\mathrm{N}_{2} \mathrm{O}$ emissions and to test possible $\mathrm{CH}_{4}$ emissions under extreme conditions, the parcel 2 has been (i) enriched with a loamy soil sampled from Villebon and (ii) put under strong anoxia by the installation of an impermeable sheet installed at $30 \mathrm{~cm}$ below the ground surface. Figure 8 shows that we obtained a high range of $\mathrm{N}_{2} \mathrm{O}$ flux, from very low to very high, as a function of fertilisation supply and level of

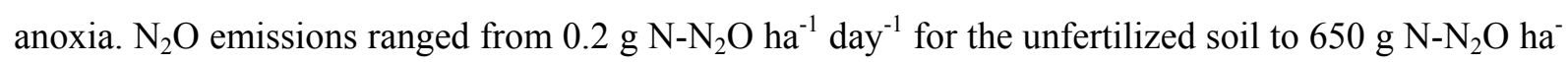
${ }^{1}$ day $^{-1}$ for the parcel 2 (highest level of nitrogen supply and strongest anoxia) on September 26 (shortly after fertilization) at the warmest time of the day. The lowest value corresponds to the detection limit for the $\mathrm{N}_{2} \mathrm{O}$ flux obtained for the $7.5 \mathrm{~cm}$ mean height of the chamber. Observation that $\mathrm{N}_{2} \mathrm{O}$ emission peaks were associated with rainfall events (in our case with irrigation) shortly after fertilizer application is in agreement with the previous reports that emission from agricultural soils is largely controlled by soil aeration and mineral N content (Sehy et al., 2003; Rochette et al., 2008). $\mathrm{N}_{2} \mathrm{O}$ emissions are strongly dependent on the diurnal cycle in September 26 and October 14, both. The soil temperature increases with the solar irradiation stimulating microbiological activities and thus $\mathrm{N}_{2} \mathrm{O}$ productions by opposition to peatland flooded soils, where the soil temperature remains constant at a daily scale. Average $\mathrm{N}_{2} \mathrm{O}$ emissions are also 7 times less intense on October 14 compared to September 26. This drop is more explained by the lack of available nitrate after 19 days rather than the lower air and soil temperature measured on October $14\left(20^{\circ} \mathrm{C}\right.$ for the air temperature at $\left.14 \mathrm{~h} \mathrm{L.T.}\right)$ than on September $26\left(23^{\circ} \mathrm{C}\right.$ for the air temperature at $\left.14 \mathrm{~h} \mathrm{L.T.}\right)$. 


\section{3. $\mathrm{CH}_{4}$ from lakes and rivers}

4.3.1. The research project. Although largely documented in tropical floodplains and reservoirs, emission of methane by lakes, rivers and wetlands was long underestimated in part due to large spatial and temporal variability (Pavel et al. 2009). Several recent surveys have indicated high fluxes of methane to the atmosphere notably from temperate water bodies. For instance, between 7 to $80 \mu \mathrm{mol}$ $\mathrm{m}^{-2} \mathrm{~h}^{-1}$ for wetlands and lakes in the Danube Delta (Pavel et al. 2009), from 8 to $40 \mu \mathrm{mol} \mathrm{m} \mathrm{m}^{-2} \mathrm{~h}^{-1}$ for different shallow water lakes studied by Bastviken et al. (2008) and even more than $190 \mu \mathrm{mol} \mathrm{m} \mathrm{m}^{-2} \mathrm{~h}^{-1}$ from a hydropower reservoir (Delsongro et al. 2010). In addition, $\mathrm{CH}_{4}$ emissions from lakes account for $6-16 \%$ of the non-anthropogenic emissions (Bastviken et al., 2004; St. Louis et al., 2000). Most data on $\mathrm{CH}_{4}$ emission come from the measurement of dissolved gas in water. Continuous rapid measurement by laser absorption spectrometry allowed us to directly determine gas flux across the water surface and potentially distinguish between diffusive and bubbling fluxes.

4.3.2. Field measurements. A preliminary test was realised on the river Loire at Orléans on November $10^{\text {th }}, 2009$. Discharge was about $122 \mathrm{~m}^{3} \mathrm{~s}^{-1}$ (less half the monthly mean discharge). Measured fluxes ranged from 8 to $28 \mu \mathrm{mol} \mathrm{m}^{-2} \mathrm{~h}^{-1}\left(22-80 \mathrm{~g} \mathrm{C}^{-} \mathrm{CH}_{4} \mathrm{ha}^{-1} \mathrm{~d}^{-1}\right)$ which compare with the data mentioned above for more organic productive water-bodies. Sources of methane in lakes and floodplains are attributed to sediments, and anoxic bottom layers or plant materials when present. In the globally oxic waters of a turbulent stream like Loire River at Orléans, methane may originate from bank sediments and abandoned channels in less hydrodynamical active area likely influenced by urban waste-waters (Abril et al 2007). Intensive spatial and temporal surveys would be necessary to better document this case study. Preliminary test also performed on a small river nearby the experimental cultivated field of the Villebon (Beauce Chartraine and Faux Perche) in March 18, 2010, show low emissions of $\mathrm{CH}_{4}$ as expected, i.g. $2.8 \mu \mathrm{mol} \mathrm{m}^{-2} \mathrm{~h}^{-1}\left(7.9 \mathrm{~g} \mathrm{C}^{-\mathrm{CH}_{4}} \mathrm{ha}^{-1} \mathrm{~d}^{-1}\right)$, but significant emissions of $\mathrm{N}_{2} \mathrm{O}$, i.g. $1.8 \mu \mathrm{mol} \mathrm{m} \mathrm{m}^{-2} \mathrm{~h}^{-1}\left(11.7 \mathrm{~g} \mathrm{~N}-\mathrm{N}_{2} \mathrm{O}\right.$ ha $\left.^{-1} \mathrm{~d}^{-1}\right)$, likely due to drainage of $\mathrm{N}_{2} \mathrm{O}$ from surrounded fertilized soils (figure 9a). For the first time, flux measurement of $\mathrm{CH}_{4}$ have been performed during daytime on June $23^{\text {th }}$ and $24^{\text {th }}$, 2010, on Lake Pavin, demonstrating the high sensitivity of SPIRIT for low $\mathrm{CH}_{4}$ emission measurements. Figure $9 \mathrm{~b}$ shows representative linear $\mathrm{CH}_{4}$ rises versus time during flux measurements performed in two places: (1) where the lowest emission was observed (close to the littoral, right part of the plot) and for the highest one (nearby the spillway of the lake, left

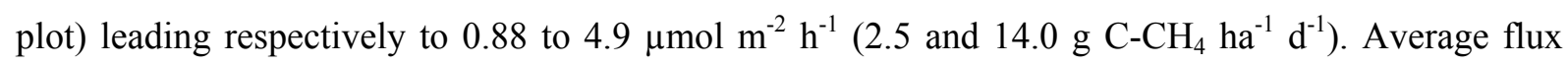

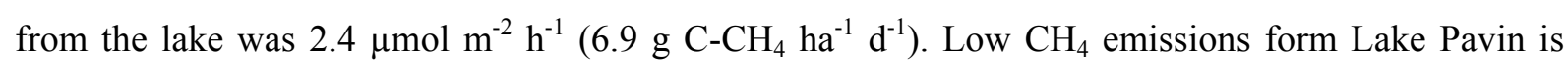
explained by the very low percentage of shallow epilimnetic sediments due to sharp border slopes, and high average depth. 


\section{Conclusions and perspectives}

SPIRIT has demonstrated its ability to measure a wide range of fluxes in various ecosystems emitting $\mathrm{N}_{2} \mathrm{O}$ and $\mathrm{CH}_{4}$ with high time and space resolutions, including efflux pathways determination. The essential advantages of this new infrared spectrometer come from the coupling of two last technology advances leading to compactness, ease use, sensitivity, accuracy and robustness: (i) the very high spectral resolution $\left(<1.5 \times 10^{-4} \mathrm{~cm}^{-1}\right)$ laser sources (QCL) working near room temperature associated with a Stirling cycle cooled detector avoiding the use of liquid nitrogen, and (ii) the multipass optical cell patented by the authors (Robert, 2007).

Thus, SPIRIT is well suited to investigate and to understand detailed processes of production, transport, and emissions of $\mathrm{N}_{2} \mathrm{O}$ and $\mathrm{CH}_{4}$ as a function of biotic and abiotic parameters including symbiosis between different part of the ecosystems (vegetation, organic matter, bacteria). This is of great importance to get a better understanding of the $\mathrm{C}$ and $\mathrm{N}$ cycles and to asses their budget in an ecosystem, as a function of soil properties, climate change and anthropogenic forcing. As a consequence, SPIRIT will evolve to support two more QCLs in order to monitor, in addition to $\mathrm{N}_{2} \mathrm{O}$ and $\mathrm{CH}_{4}$, fluxes of $\mathrm{CO}_{2}$ (for $\mathrm{C}$ balance determination) as well as trace gases uneasily measurable by other instruments that are of a great importance in climate change. These could be HCHO and HONO as they play a key role in the oxidation capacity of the atmosphere. By addition of a reference cell as described in section 3, SPIRIT could be also upgraded for the direct measurement of isotopic ratios, and then for the $\delta$ value of ${ }^{13} \mathrm{C} /{ }^{12} \mathrm{C}$ isotopic ratio determination for $\mathrm{CO}_{2}$ (Bowling et al., 2003; Mondelain et al., 2008) and $\mathrm{CH}_{4}$ (Tsuji et al., 2006), which is of prime importance to study biogeochemical mechanisms involving $\mathrm{CO}_{2}$ (Rochette et al., 1999) and $\mathrm{CH}_{4}$ (Whiticar 1999).

We have demonstrated that the use of a high temporal resolution spectrometer $(1.5 \mathrm{~s})$ is needed to assess on line measurement artefacts and emission pathways, even for fluxes derived from chamber methods when investigations are made at the vegetation scale. To investigate gas emissions at an upper scale, SPIRIT can be adapted to the Eddy Covariance technique. A sampling rate of $10 \mathrm{~Hz}$ is generally preferred for EC in order to obtain the best estimates of fluxes for $\mathrm{CH}_{4}$ (Hendriks et al., 2008) and for $\mathrm{N}_{2} \mathrm{O}$ (Neftel et al. 2010). Measurements performed at $1 \mathrm{~Hz}$ can also generate reliable results (Neftel et al. (2010) and can be sufficient at measurements heights above $2 \mathrm{~m}$ for $\mathrm{CH}_{4}$ and $\mathrm{N}_{2} \mathrm{O}$ in natural and agricultural ecosystems (Edwards et al. 2003). By the installation of a smaller optical absorption cell and minor modifications of the instrument, SPIRIT can meet criteria for EC. SPIRIT's software and hardware are currently configured to operate with 3 switched lasers with a period of measurement of averaged spectra of $1.5 \mathrm{~s}$. When using a single laser in a continuous mode, this period can be reduced to $0.5 \mathrm{~s}$ allowing for a $2 \mathrm{~Hz}$ frequency for $\mathrm{CH}_{4}$ and $\mathrm{N}_{2} \mathrm{O}$ volume mixing ratio without any lost for precision. This frequency can be also increased up to 3 or $4 \mathrm{~Hz}$ with only few 
modifications of the software by reducing (i) the period of each saw-tooth ramp, implying the decrease of the number of points for each ramp (this solution would decrease slightly the resolution of the spectra) or (ii) the number of averaged saw-tooth ramp (this solution would reduce the signal-to-noise ratio).

\section{Acknowledgements}

The technical team of the LPC2E, and more specifically G. Chalumeau, S. Chevrier, F. Savoie and T. Vincent, are gratefully acknowledged for their contribution to SPIRIT development and their participation to the field campaigns.

The paper is a contribution to the research conducted at the OSUC (Observatoire des Sciences de l’Univers en région Centre) supported by the following projects:

- SPATIOFLUX (investigation of GHG flux emissions from natural and cultivated ecosystems located in the Region Centre in France), lead by the French agronomy national research institute (INRAOrléans), funded by the Region Centre (2007-2013) and supported by the RESONAT (financial support from INRA, Région Centre and FEDER) consortium of institutes (INRA : OSUC : BRGM) located in the area of Orléans.

Philippe Rochette and Normand Bertrand, for the concentration measurements of $\mathrm{N}_{2} \mathrm{O}$ and $\mathrm{CH}_{4}$ by $\mathrm{CG}$ in comparison with SPIRIT, Agrométéorologue/Agrometeorologist Agriculture et agroalimentaire Canada/ Agriculture and Agri-Food Canada 2560, Boul Hochelaga Québec, QC Canada G1V 2J3.

\section{References}

Abril G, Commarieu M V and Guerin F 2007 Enhanced methane oxidation in an estuarine turbidity maximum Limnology and Oceanography 52 470-5

Bastviken D, Cole J, Pace M and Tranvik L 2004 Methane emissions from lakes: Dependence of lake characteristics, two regional assessments, and a global estimate Global Biogeochem. Cycles 18 doi:10.1029/2004GB002238

Bastviken D, Cole J J , Pace M L and Van de Bogert M C 2008 Fates of methane from different lake habitats: Connecting whole-lake budgets and $\mathrm{CH}_{4}$ emissions J. Geophys. Res. 113 G02024 doi:10.1029/2007JG000608

Beck M, Hofstetter D, Aellen, T, Faist J, Oesterle U, Ilegems M, Gini E and Melchior H 2002 Continuous wave operation of a mid-infrared semiconductor laser at room temperature Science 295 $301-5$ 
Belyea L R and Malmer N 2004 Carbon sequestration in peatland: patterns and mechanisms of response to climate change Global Change Biology 10 1043-52

Berthet G, Huret N, Lefèvre F, Moreau G, Robert C, Chartier M, Catoire V, Barret B, Pisso I and Pomathiod L 2006 On the ability of chemical transport models to simulate the vertical structure of the $\mathrm{N}_{2} \mathrm{O}, \mathrm{NO}_{2}$ and $\mathrm{HNO}_{3}$ species in the mid-latitude stratosphere Atmos. Chem. Phys. 6 1599-609

Berthet G, Renard J B, Catoire V, Chartier M, Robert C, Huret N, Coquelet F, Bourgeois Q, Rivière E D, Barret B, Lefèvre F and Hauchecorne A 2007 Remote sensing measurements in the polar vortex: comparison to in situ observations and implications for the simultaneous retrievals and analysis of the $\mathrm{NO}_{2}$ and OClO species J. Geophys. Res. 112 D21310, doi:10.1029/2007JD008699

Bertseva E, Kachanov A A and Campargue A 2002 Intracavity laser absorption spectroscopy of $\mathrm{N}_{2} \mathrm{O}$ with a vertical external cavity surface emitting laser, Chemical Physics Letters 351 18-26

Bortolluzi E, Epron D, Siegenthaler A, Gilbert D and Buttler A 2006 Carbon balance of a European mountain bog at contrasting stages of regeneration New Phytologist 172 708-18

Bowling D R, Sargent S D, Tanner B D and Ehleringer J R 2003 Tunable diode laser absorption spectroscopy for ecosystem-atmosphere $\mathrm{CO}_{2}$ isotopic exchange studies Agricultural and Forest Meteorology 118 1-19

Comas X, Slater L and Reeve A 2008 Seasonal geophysical monitoring of biogenic gases in a northern peatland: Implications for temporal and spatial variability in free phase gas production rates $J$. Geophysical research 113 G01012, doi: 10.1029/2007JG000575

Crutzen P J, Mosier A R, Smith K A and Winiwarter W $2008 \mathrm{~N}_{2} \mathrm{O}$ release from agro-biofuel production negates global warming reduction by replacing fossil fuels Atmos. Chem. Phys. 8 389-95

Davidson E A, Keller M, Erickson H E, Verchot L V and Veldkamp E 2000 Testing a conceptual model of soil emissions of nitrous and nitric oxides Bioscience 50 667-80

Davidson E A, Savage K, Verchot L V and Navarro R 2002 Minimizing artefacts and biases in chamber based measurements of soil respiration Agricultural and Forest Meteorology 113 21-37

Delarue F, Laggoun-Défarge F, Disnar J R, Lottier N and Gogo S in press 2010 Organic sources and decay assessment in a /Sphagnum/-dominated peatland (Le Forbonnet, Jura Mountains, France): impact of moisture conditions Biogeochemistry

Delsongro T, McGinnis D F, Sobek S, Ostrovsky I and Wehrli B 2010 Extreme methane emissions from a Swiss hydropower reservoir: Contribution from bubbling sediments Environ. Sci. Technol 44 $2419-25$ 
Edwards G C, Thurtell, G W, Kidd G E, Dias G M and Wagner-Riddle C 2003 A diode laser based gas monitor suitable for measurement of trace gas exchange using micrometeorological techniques Agricultural and Forest Meteorology 115 71-89

Falkowski P, Scholes R J, Boyle E, Canadell J, Canfield D, Elser J, Gruber N, Hibbard K, Högberg P, Linder S, Mackenzie F T, Moore B, Pedersen T, Rosenthal Y, Seitzinger S, Smetacek V and Steffen W 2000 The Global Carbon Cycle: A Test of Our Knowledge of Earth as a System,Science $290291-$ 26

Firestone M K and Davidson E A 1989 Microbiological basis of $\mathrm{NO}$ and $\mathrm{N}_{2} \mathrm{O}$ production and consumption in soil, in: Andreae M O and Schimel D S (eds), Exchange of trace gases between terrestrial ecosystems and the atmosphere, Wiley, Chichester

Flessa H, Ruser R, Schilling R, Loftfield N, Munch J C, Kaiser E A and Beese F $2002 \mathrm{~N}_{2} \mathrm{O}$ and $\mathrm{CH}_{4}$ fluxes in potato fields : automated measurement, management effects and temporal variation Geoderma 105 307-25

Fried A, Henry B, Wert B, Sewell S and Drummond J R 1998 Laboratory, ground-based, and airborne tunable diode laser systems: Performance characteristics and applications in atmospheric studies Appl Phys. B. 67 317-30

Granli T and Bøckman O C 1994 Nitrous oxide from agriculture, Norwegian Journal of Agricultural Sciences supply 12 1-128

Gogo S, Laggoun-Défarge F, Delarue F and Lottier N 2010a Invasion of a Sphagnum-peatland by Betula spp and Molinia caerulea impacts organic matter biochemistry Implications for carbon and nutrient cycling Biogeochemistry DOI : 10.1007/s10533-010-9433-6

Gogo S, Guimbaud C, Laggoun-Défarge F, Catoire V, Robert C 2010b In situ quantification of $\mathrm{CH}_{4}$ bubbling events from a peat soil using a new infrared laser spectrometer Journal of Soil and Sediment DOI : 10.1007/s11368-011-0338-3

Gogo S, Guimbaud C, Laggoun-Défarge F, Catoire V, Albéric P, Robert C submitted 2010c Spatial variability of soil temperature impacts $\mathrm{CH}_{4}$ emission in a temperate Sphagnum-peatland invaded by vascular plants, wetlands, in preparation

Gorham E 1991 Northern peatlands: role in the carbon cycle and probable responses to climatic warming Ecol. Appl. 1 182-95

Guenther A, Baugh W, Davis K, Hampton G, Harley P, Klinger L, Zimmerman P, Allwine E Dilts S, Lamb B, Westberg H, Baldocchi D, Geron C and Pierce T 1996 Isoprene fluxes measured by enclosure, relaxed eddy accumulation, surface-layer gradient, mixed-layer gradient, and mass balance techniques J. Geophys. Res. 101 555-68 
Hénault C, Bizouard F, Laville P, Gabrielle B, Nicoullaud B, Germon J C and Cellier P 2005

Predicting in situ soil $\mathrm{N}_{2} \mathrm{O}$ emission using NOE algorithm and soil database Global Change Biology 11 115-27 DOI: 10.1111/j.1365-2486.2004.00879.x

Hendriks D M D, Dolman A J, van der Molen M K and van Huissteden J, 2008 A compact and stable eddy covariance set-up for methane measurements using off-axis integrated cavity output spectroscopy Atmos. Chem. Phys. 8 431-43

Hendriks D M D, Van Huissteden J and Dolman A J 2010 Multi-technique assessment of spatial and temporal variability of methane fluxes in a peat meadow Agric. For. Meteorol. 150 757-74

Herndon S C, Zahniser M S, Nelson Jr D D, Shorter J, McManus J B, Jiménez R, Warneke C and de Gouw J A 2007 Airborne measurements of $\mathrm{HCHO}$ and $\mathrm{HCOOH}$ during the New England Air Quality Study 2004 using a pulsed quantum cascade laser spectrometer J. Geophys. Res. 112 D10S03, doi:10.1029/2006JD007600,

Huret N, Pirre M, Hauchecorne A, Robert C and Catoire V 2006 On the vertical structure of the stratosphere at midlatitudes during the first stage of the polar vortex formation and in the polar region in the presence of a large mesospheric descent J. Geophys. Res. 111 D06111, doi:10.1029/2005JD006102,

Hutchinson G L and Livingston G P 2001 Vents and seals in non-steady-state chambers used for measuring gas exchange between soil and the atmosphere Eur. J. Soil Sci. 52 675-82

IPCC Fourth Assessment Report (AR4) by Working Group 1 (WG1), Chapter 2 "Changes in Atmospheric Constituents and in Radiative Forcing", 2007a

IPCC Fourth Assessment Report 2007: The AR4 Synthesis report : Chapter 7: "Couplings Between Changes in the Climate System and Biogeochemistry", 2007b

IPCC Fourth Assessment Report 2007: WGII : Impacts, Adaption and Vulnerability : Chapter 4: "Ecosystems, their Properties, Goods and Services", 2007c

Jégou F, Urban J, de La Noë J, Ricaud P, Le Flochmo“en E Murtagh D P, Eriksson P, Jones A, Petelina S, Llewellyn E J, Lloyd N D, Haley C, Lumpe J, Randall C, Bevilacqua R M, Catoire V, Huret N, Berthet G, Renard J B, Strong K, Davies J, Mc Elroy C T, Goutail F and Pommereau J P 2008 Technical Note: Validation of Odin/SMR limb observations of ozone, comparisons with OSIRIS, POAM III, ground-based and balloon-borne instruments Atmos. Chem. Phys. 8 3385-409

Joly L, Robert C, Parvitte B, Catoire V, Durry G, Richard G, Nicoullaud B and Zéninari V 2008 Development of a spectrometer using a cw DFB quantum cascade laser operating at room temperature for the simultaneous analysis of $\mathrm{N}_{2} \mathrm{O}$ and $\mathrm{CH}_{4}$ in the Earth's atmosphere Applied Optics 47 1206-14 
Kosterev A A, Curl R F, Tittel F K, Gmachl C, Capasso F, Sivco D L Baillargeon,J N, Hutchinson A L and Cho A Y 2000 Effective utilization of quantum-cascade distributed-feedback lasers in absorption spectroscopy Applied optics 39 4425-30

Kroon P S, Hensen A, Zahniser M S, van't Veen H and Vermeuken A T 2007 Suitability of quantum cascade laser spectrometry for $\mathrm{CH}_{4}$ and $\mathrm{N}_{2} \mathrm{O}$ eddy covariance measurements Biogeosciences 4 715-28

Kroon P S, Hensen A, van den Bulk W C M, Jongejan P A C, Vermeulen AT 2008 The importance of reducing the systematic error due to non-linearity in $\mathrm{N}_{2} \mathrm{O}$ flux measurements by static chambers Nutr. Cycl. Agroecosyst. 82 175-86

Laville P, Henault C, Renault P, Cellier P, Oriol A, Devis X, Flura D and Germon J C 1997 Field comparison of nitrous oxide emission measurements using micrometeorological and chamber methods Agronomie 17 375-88

Laville P, Jambert C, Cellier P and Delmas R 1999 Nitrous oxide fluxes from a fertilised crop using micrometeorological and chamber methods Agricultural and Forest Meteorology 96 19-38

Los Gatos Research Inc., CA, USA : http://www.lgrinc.com/analyzers/index.php

McManus J B, Zahniser M S, Nelson D D, Shorter J H, Herndon S, Wood E, Wehr R 2010 Application of quantum cascade lasers to high-precision atmospheric trace gas measurements Optical Engineering 49 doi:10.1117/1.3498782

McManus J B, Zahniser M S, Nelson D D 2011 Dual quantum cascade laser trace gas instrument with astigmatic Herriott cell at high pass number Applied Optics 50 A74-A85

Mébarki Y, Catoire V, Huret N, Berthet G, Robert C and Poulet G 2010 More evidence for very shortlived substance contribution to stratospheric chlorine inferred from $\mathrm{HCl}$ balloon-borne in situ measurements in the tropics Atmos. Chem. Phys. 10 1-13

Mondelain D, Croizé L, Camy-Peyret C, Delmotte M, Schmidt M 2008 Precise atmospheric ${ }^{13} \mathrm{CO}_{2} /{ }^{12} \mathrm{CO}_{2}$ isotopic ratio measurements using a lead-salt laser diode spectrometer Rev. Sci. Instrum. 79 043101, doi:10.1063/1.2902829

Moreau G, Robert C, Catoire V, Chartier M, Camy-Peyret C, Huret N, Pirre M, Pomathiod L and Chalumeau G 2005 SPIRALE: A multispecies in situ balloon-borne experiment with six tunable diode laser spectrometers Appl. Opt. 44 5972- 89

Müller R, Tilmes S, Grooß J U, Engel A, Oelhalf H, Wetzel G, Huret N, Pirre M, Catoire V, Toon G and Nakajima H 2007 Impact of mesospheric intrusions on ozone-tracer relations in the stratospheric polar vortex J. Geophys. Res. 112 D23307, doi:10.1029/2006JD008315 
Nelson D D, McManus B, Urbanski S, Herndon S and Zahniser M S 2004 High precision measurements of atmospheric nitrous oxide and methane using thermoelectrically cooled mid-infrared quantum cascade lasers and detectors Spectrochimica Acta Part A 60 3325-35

Neftel A, Ammann C, Fischer C, Spirig C, Conen F, Emmenegger L, Tuzson B and Wahlen S 2010 $\mathrm{N}_{2} \mathrm{O}$ exchange over managed grassland: Application of a quantum cascade laser spectrometer for micrometeorological flux measurements Agric. For. Meteorol. 150 775-85

Pavel A, Durish-Kaiser E, Balan S, Radan S, Sobek S and Wehrli B 2009 Sources and emissions of greenhouse gases in Danube Delta lakes Environ Sci. Pollut. Res. 16 (Suppl 1) 86-91

Picarro Inc., CA, USA : http://www.picarro.com/

Pirre M, Pisso I, Marécal V, Catoire V, Mébarki Y and Robert C 2008 Intrusion of recent air in midlatitude stratosphere revealed by in situ tracer measurements and trajectory calculations $J$ Geophys. Res. 113 D11302, doi: 10.1029/2007JD009188

Renard J B, Berthet G, Brogniez C, Catoire V, Fussen D, Goutail F, Oelhaf H, Pommereau J P, Roscoe H K, Wetzel G, Chartier M, Robert C, Balois J Y, Verwaerde C, Auriol F, François P Gaubicher B and Wursteisen P 2008 Validation of GOMOS-Envisat vertical profiles of $\mathrm{O}_{3}, \mathrm{NO}_{2}, \mathrm{NO}_{3}$, and aerosol extinction using balloon-borne instruments and analysis of the retrievals J. Geophys. Res. 113 A02302, doi:10.1029/2007JA012345

Robert C 2007 Multipass cell: International Patent (WO 2007/017570 A1)

Robert C 2007 Simple, stable, and compact multiple-reflection optical cell for very long optical paths Appl. Opt. 46 5408-18

Rochette P and Flanagan L B et E G G 1999 Separating soil respiration into plant and soil components using analyses of the natural abundance Soil Science Society of America Journal 63 120713

Rochette P and Bertrand N 2008 Soil-surface gas emissions, in: Carter, M R, Gregorich E G (Eds), Soil sampling and methods of analysis 2nd edition CRC Press, Boca Raton, FL, USA, 851-61

Rochette P, Eriksen-Hamel N S, 2008 Chamber measurements of soil nitrous oxide flux: are absolute values reliable? Soil Sci. Soc. Am. J. 72 331-42

Romanini D, Chenevier M, Kassi S, Schmidt M, Valant C, Ramonet M, Lopez J and Jost H J 2006 Optical-feedback cavity-enhanced absorption: a compact spectrometer for real-time measurement of atmospheric methane Appl. Phys. B 83 659-67

Rothman L S, Gordon I E, Barbe A, Benner C D, Bernath P F, Birk M, Boudon V, Brown L R , Campargue A, Champion, J P, Chance K, Coudert L H, Dana V, Devi V M, Fally S, Flaud J M, 
Gamache R R, Goldman A, Jacquemart D, Kleiner I, Lacome N, Lafferty W J, Mandin, J Y, Massie S T, Mikhailenko S N, Miller C E, Moazzen-Ahmadi N, Naumenko O V, Nikitin A V, Orphal J, Perevalov V I, Perrin A, Predoi-Cros A, Rinsland C P, Rotger M, Simeckova M, Smith M A H, Sung K, Tashkun S A, Tennyson J, Toth R A, Vandaele A C and Van der Auwera J 2009 The HITRAN 2008 molecular spectroscopic database J. Quant. Spectrosc. Radiat. Transf. 96 139-204

Schrier-Uijl A P, Kroon P S, Hensen A, Leffelaar P A, Berendse F and Veenendaal E M 2010 Comparison of chamber and eddy covariance-based $\mathrm{CO}_{2}$ and $\mathrm{CH}_{4}$ emission estimates in a heterogeneous grass ecosystem on peat Agricultural and Forest Meteorology 150 825-31

Sehy U, Ruser R and Munch J C 2003 Nitrous oxide fluxes from maize fields, relationship to yield, site-specific fertilization, and soil condition Agriculture, Ecosystems \& Environment 99 97-111

Skrinsky J, Janeckova R, Grigorova E, Strizik M, Kubat P, Herecova L, Nevrly V, Zelinger Z and Civiš S 2009 Allan variance for optimal signal averaging-monitoring by diode-laser and $\mathrm{CO}_{2}$ laser photo-acoustic spectroscopy Journal of Molecular Spectroscopy 256 99-101

Strong K, Wolff M A, Kerzenmacher T E, Walker K A, Bernath P F, Blumenstock T, Boone C, Catoire V et al 2008 Validation of ACE-FTS $\mathrm{N}_{2} \mathrm{O}$ measurements Atmos. Chem. Phys. 8 4759-86

St. Louis V L, Kelly C A, Duchemin E, Rudd J W M and Rosenberg D M 2000 Resevior surfaces as sources of greenhouse gases to the atmosphere: A global estimate, Bioscience 50 766-75 doi:10.1641/0006-3568(2000)050[0766:RSASOG]2.0.CO;

Thormann M N, Szumigalski A R and Bayley S E 1999 Aboveground peat and carbon accumulation potentials along a bog-fen-marsh wetland gradient in southern boreal Alberta, Canada Wetlands 19,305-17

Tsuji K, Fujikawa S, Yamada K, Yoshida N, Yamamoto K and Kikugawa T 2006 Precise measurement of the ${ }^{13} \mathrm{CH}_{4} /{ }^{12} \mathrm{CH}_{4}$ ratio of diluted methane using a near-infrared laser absorption spectrometer Sensors and Actuators B 114 326-33

Tuzson B, Hiller R V, Zeyer K, Eugster W, Neftel A, Ammann C and Emmenegger L 2010 Field intercomparison of two optical analyzers for $\mathrm{CH}_{4}$ eddycovariance flux measurements Atmos. Meas. Tech. 3 1519-1531

Wang D Y, Hopfner M, Blom C E, Ward W E, Fischer H, Blumenstock T, Hase F, Keim C, Liu G Y, Mikuteit S, Oelhaf H, Wetzel G, Cortesi U, Mencaraglia F, Bianchini G, Redaelli G, Pirre M, Catoire V, Huret $\mathrm{N}$ et al 2007 Validation of MIPAS $\mathrm{HNO}_{3}$ operational data Atmos. Chem. Phys. 7 4905-4934

Werle P, Mucke R and Slemr F 1993 The limits of signal averaging in atmospheric trace-gas monitoring by tunable diode-laser absorption spectroscopy (TDLAS) Appl. Phys. B. 57 131-139 
Whiticar M J 1999 Carbon and hydrogen isotope systematics of bacterial formation and oxidation of methane Chem. Geol. 16 291-314 
Table 1. Unit expressions for the flux of an i species $\left(\mathrm{F}^{\mathrm{S}} \mathrm{i}\right)$ according to Eq. (3) and associated values of A.

\begin{tabular}{|c|c|}
\hline Value of $A$ & Unit expression of $\mathrm{F}_{\mathrm{i}}^{\mathrm{S}}$ \\
\hline $7.241 \times 10^{9}$ & molecule $\mathrm{cm}^{-2} \mathrm{~s}^{-1}$ \\
\hline 0.1202 & $\mathrm{n} \mathrm{mol} \mathrm{m} \mathrm{m}^{-2} \mathrm{~s}^{-1}$ \\
\hline 3.366 & ng N-N $\mathrm{O} \mathrm{m}^{-2} \mathrm{~s}^{-1}$ \\
\hline 2.910 & $\mathrm{~g} \mathrm{~N}-\mathrm{N}_{2} \mathrm{O} \mathrm{ha}^{-1} \mathrm{~J}^{-1}$ \\
\hline $1.213 \times 10^{-2}$ & $\mathrm{mg} \mathrm{N}-\mathrm{N}_{2} \mathrm{O} \mathrm{m}^{-2} \mathrm{~h}^{-1}$ \\
\hline 1.443 & ng C-CH $4 \mathrm{~m}^{-2} \mathrm{~s}^{-1}$ \\
\hline 1.247 & $\mathrm{~g} \mathrm{C}^{-\mathrm{CH}_{4}} \mathrm{ha}^{-1} \mathrm{~J}^{-1}$ \\
\hline $5.196 \times 10^{-3}$ & $\mathrm{mg} \mathrm{C}-\mathrm{CH}_{4} \mathrm{~m}^{-2} \mathrm{~h}^{-1}$ \\
\hline
\end{tabular}


Table 2. Range of methane emission on March 19, in La Guette's peatland.

\begin{tabular}{ccc} 
Vegetation & \multicolumn{2}{c}{ Flux range } \\
& $\mathrm{mg} \mathrm{C} \mathrm{m}^{-2} \mathrm{~h}^{-1}$ & $\left(\mathrm{~g} \mathrm{C} \mathrm{ha}^{-1} \mathrm{day}^{-1}\right)$ \\
\hline Eriophorum & $1.08-1.71$ & $(260-410)$ \\
Sphagnum cuspidatum & $0.88-1.00$ & $(210-240)$ \\
Betula spp. & $0.58-0.67$ & $(140-160)$ \\
Sphagnum rubellum & $0.29-0.54$ & $(70-130)$ \\
\hline
\end{tabular}


Table 3. Soil treatment before first measurements on September 26, and October 14, 2008.

\begin{tabular}{|c|c|c|c|}
\hline Parcel label & Reference & 1 & 2 \\
\hline Ploughing date & $15 / 06 / 08$ & $15 / 06 / 08$ & $15 / 06 / 08$ \\
\hline Horse manure on $26 / 06 / 08(\mathrm{t} / \mathrm{ha})$ & 0 & 65 & 65 \\
\hline Horse manure on $29 / 08 / 08(\mathrm{t} / \mathrm{ha})$ & 0 & 34 & 34 \\
\hline \multicolumn{4}{|l|}{ Nitrogen fertilizers on $29 / 08 / 08$} \\
\hline (kg N/ha, solid form) & 0 & 75 & 75 \\
\hline Compaction date & 08/09/08 & 08/09/08 & 08/09/08 \\
\hline Cylinder collar installation date & $15 / 09 / 08$ & $15 / 09 / 08$ & $15 / 09 / 08^{\mathrm{a}}$ \\
\hline \multicolumn{4}{|l|}{ Nitrogen fertilizers on $24 / 09 / 08$} \\
\hline (kg N/ha, liquid form) & 0 & 100 & 150 \\
\hline \multicolumn{4}{|l|}{ Watering (mm) } \\
\hline $24 / 09 / 08$ & 30 & 30 & 30 \\
\hline $25 / 09 / 08$ & 5 & 10 & 10 \\
\hline 26/09/08 (8h30 L.T.) & & 3 & 3 \\
\hline $09 / 10 / 2008$ & 15 & 15 & 15 \\
\hline $10 / 10 / 2008$ & 5 & 5 & 5 \\
\hline $13 / 10 / 2008$ & 25 & 25 & 25 \\
\hline $14 / 10 / 2008$ & 3 & 3 & 3 \\
\hline
\end{tabular}

${ }^{\text {a }}$ mixte with faux Perche loamy soil and put under strong anoxia by the installation of an impermeable sheet installed at $30 \mathrm{~cm}$ below the ground surface. 


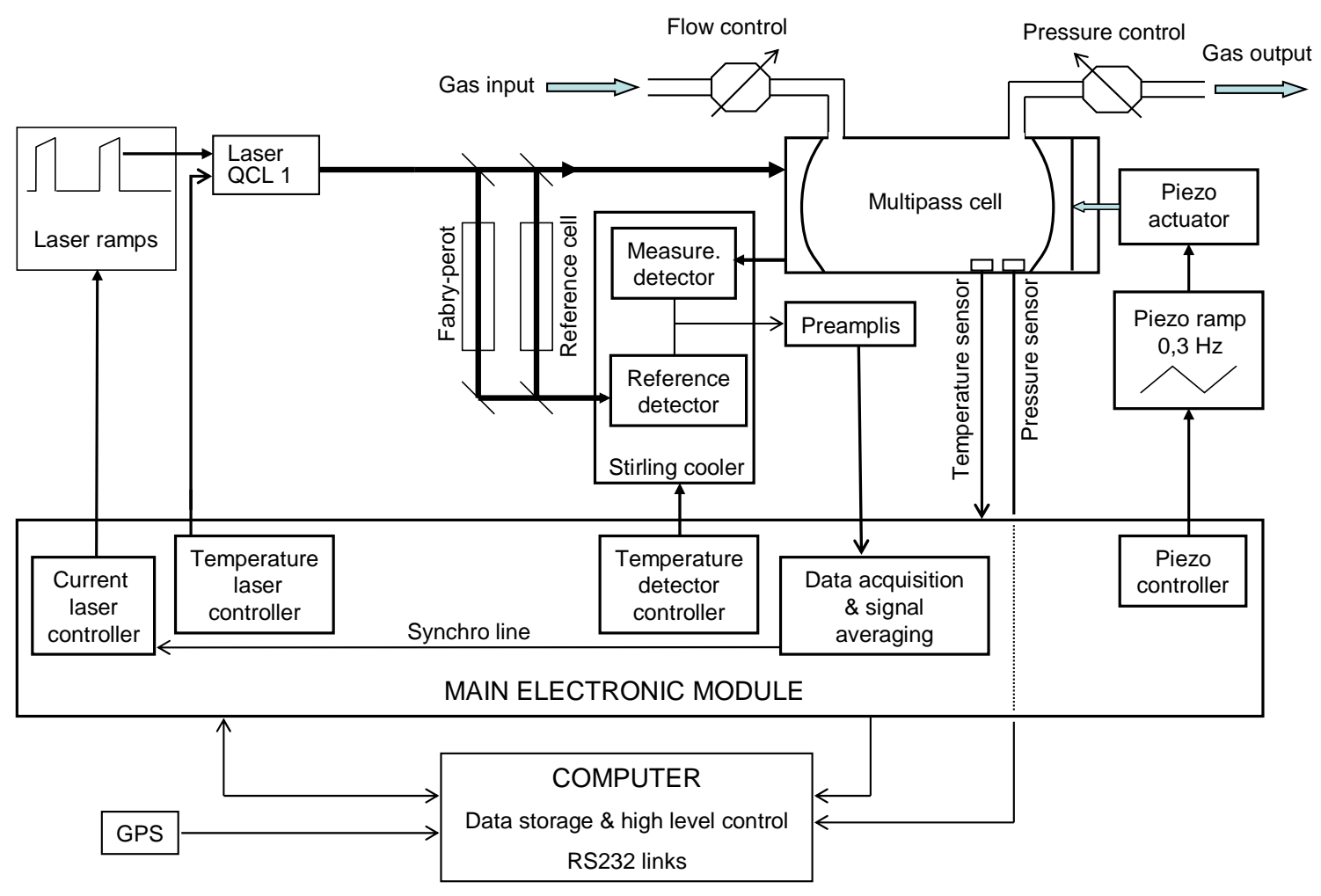

Figure 1. Schematics of the instrument principle 


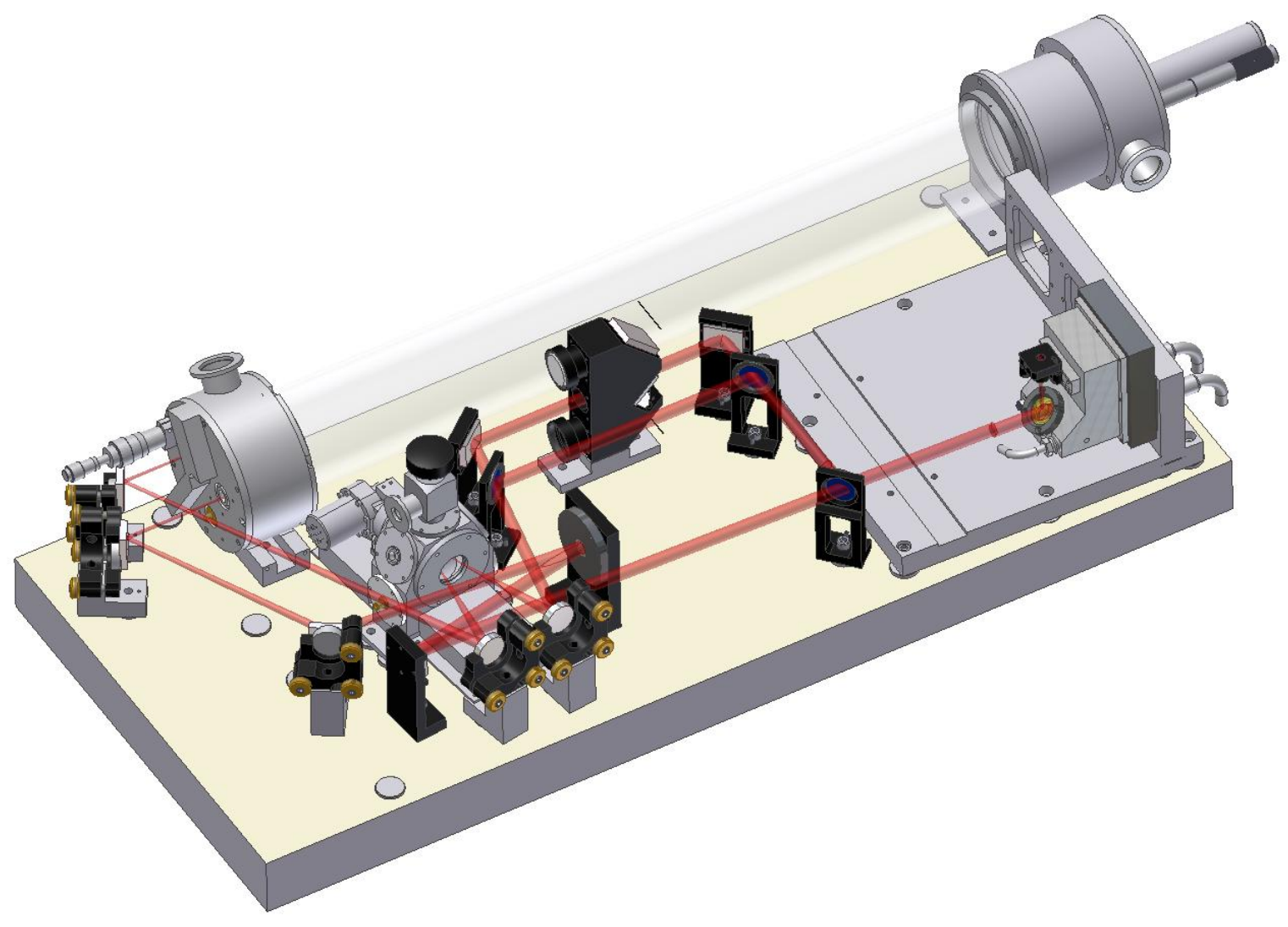

Figure 2. Schematics of the optical bench. The path of the laser beam is symbolized by a red ray. 


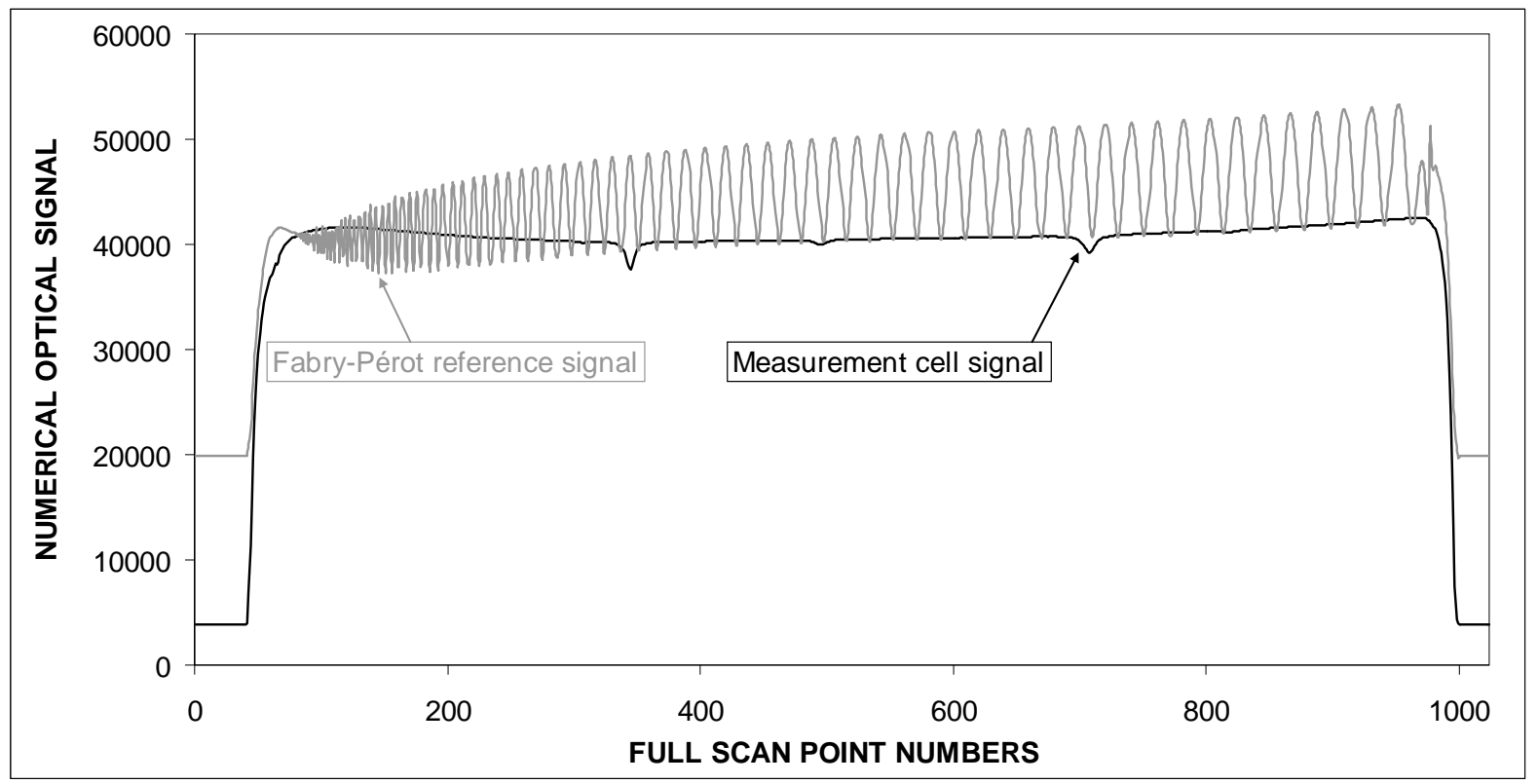

Figure 3. Average raw signals of 110 measurements (black curve), with 8 superimposed Fabry-Pérot reference signal (gray curve), recorded at $35.80 \mathrm{hPa}$ and $15.90^{\circ} \mathrm{C}$. 

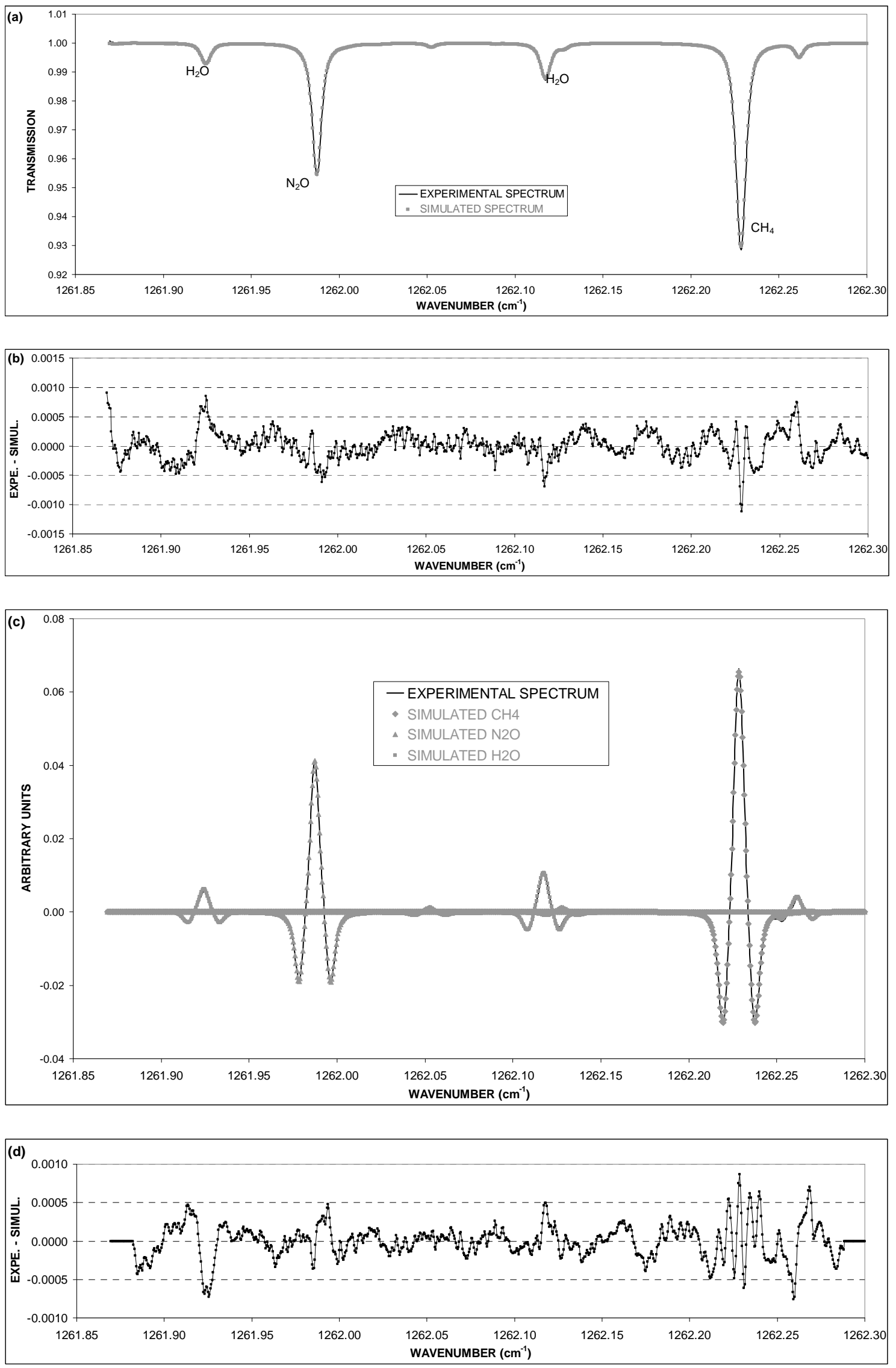
Figure 4. (a) Example of experimental (black curve) and simulated (gray squares) transmission spectra with (b) the associated residual, i.e. (experiment - simulated) signal; (c) Experimental (black curve) and simulated second derivatives of the $\mathrm{CH}_{4}$ (grey diamonds), $\mathrm{N}_{2} \mathrm{O}$ (grey triangles) and $\mathrm{H}_{2} \mathrm{O}$ (grey squares) transmission spectra with (d) the associated residual. This analysis leads to volume mixing ratios of $2001.1 \mathrm{ppb} \mathrm{CH}_{4}, 323.25 \mathrm{ppb} \mathrm{N}_{2} \mathrm{O}$ and $0.7379 \% \mathrm{H}_{2} \mathrm{O}$, with $1 \sigma$ statistical uncertainties of $0.50 \%, 0.42 \%$ and $2.48 \%$, respectively. Pressure was $35.80 \mathrm{hPa}$ and temperature was $15.90{ }^{\circ} \mathrm{C}$.

The high residual for the left $\mathrm{H}_{2} \mathrm{O}$ line (around $1261.92 \mathrm{~cm}^{-1}$ ) is explained by a poor line fit because its spectroscopic parameters are not well characterized in the Hitran database, and the retrieval includes the simultaneous fitting of three $\mathrm{H}_{2} \mathrm{O}$ lines (with those at 1262.12 and $\left.1262.27 \mathrm{~cm}^{-1}\right)$. 


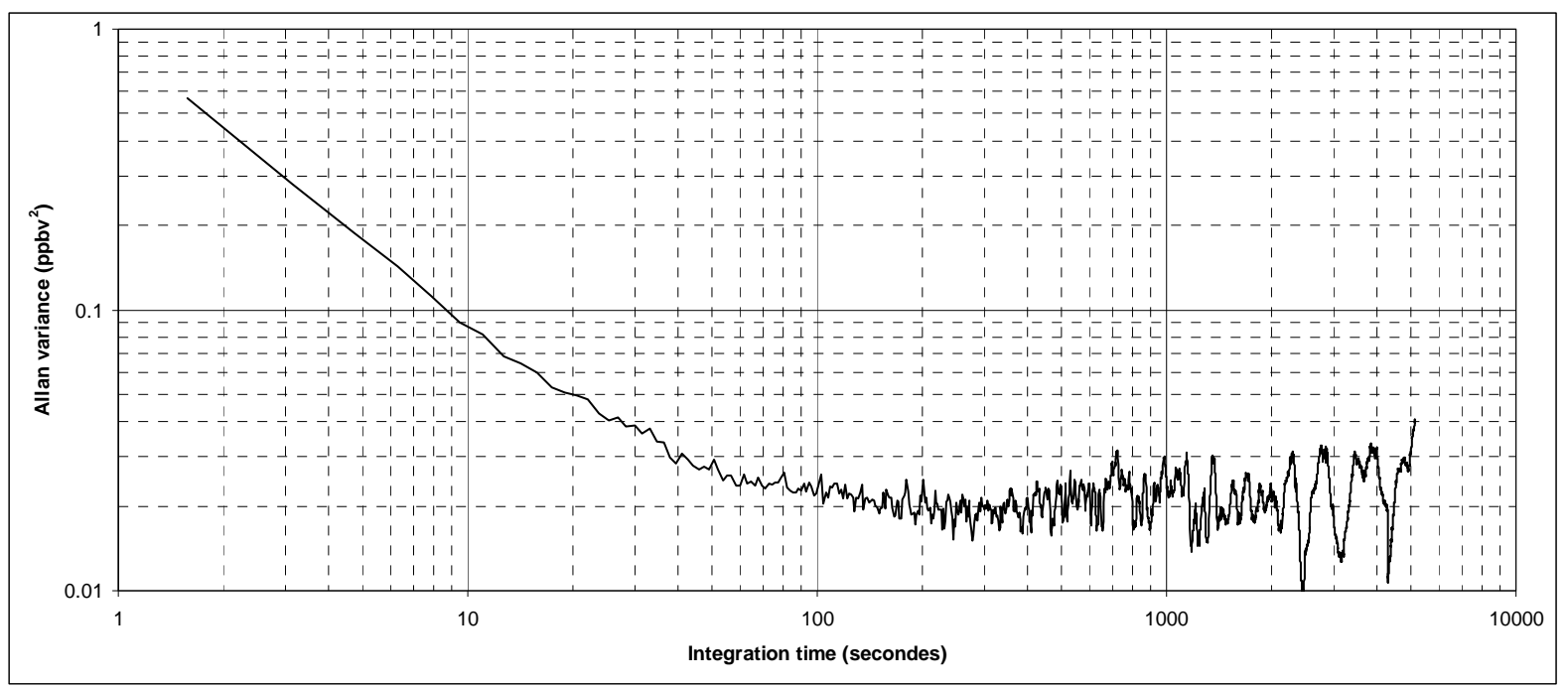

Figure 5. $\mathrm{N}_{2} \mathrm{O}$ Allan plot showing long term precision and drift behaviour using room laboratory air. 

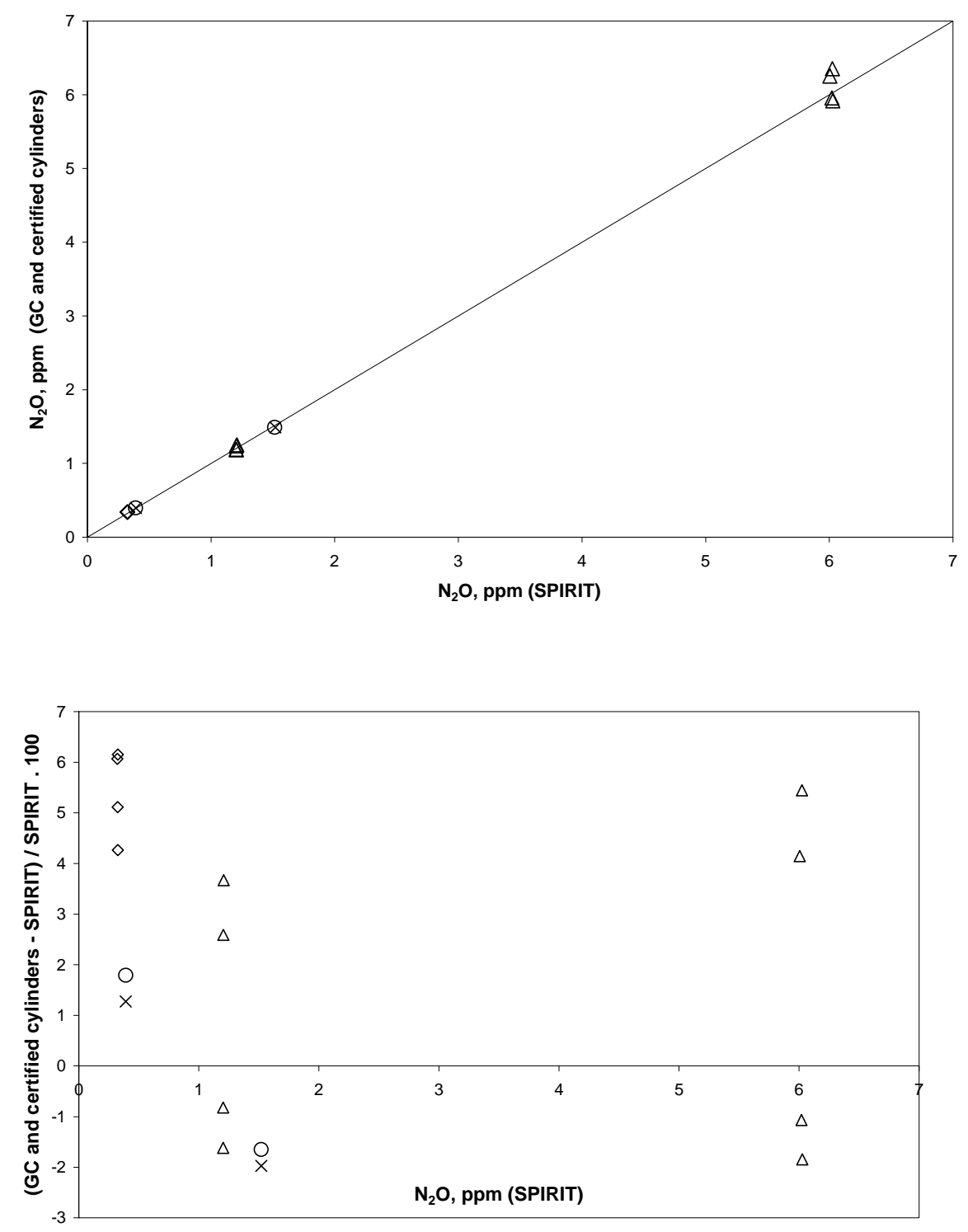

Figure 6. (a) $\mathrm{N}_{2} \mathrm{O}$ volume mixing ratios: Gas phase Chromatography (GC) and certified $\mathrm{N}_{2} \mathrm{O}$ pressurized cylinders versus infra red spectrometry (SPIRIT) (b) Relative difference in per cent versus SPIRIT to show the $\mathrm{Y}$ axis scattering of the data.

Diamonds and triangles: $\mathrm{GC}$ versus SPIRIT from $\mathrm{N}_{2} \mathrm{O}$ prepared bulbs in April 2009; diamonds: 4 samples from $\mathrm{N}_{2} \mathrm{O}$ ambient air ; triangles : 8 samples from $\mathrm{N}_{2} \mathrm{O}$ doped dry air. Good agreement between GC (accuracy $<3 \%$ ) and SPIRIT (accuracy $<6 \%$ ) are obtained (more details given in the text). Data from GC are likely overestimated because a high ambient air averaged mixing ratio is 
found (341 ppb) for GC diamond data compared to SPIRIT (324 ppb), where the latter one agree more with the expected ambient air volume mixing ratio from IPCC (2007).

Circles and crosses: Certified $\mathrm{N}_{2} \mathrm{O}$ pressurized cylinders standards vs SPIRIT; $\mathrm{N}_{2} \mathrm{O}$ standards were independently prepared from Air Liquide ${ }^{\circledR}$ in dry $\mathrm{N}_{2}$ pressurized cylinders where mixing ratios ( $397 \pm 8 \mathrm{ppb}$ and $1490 \pm 30 \mathrm{ppb}$ ) are certified from the BIPM (Bureau International des Poids et Mesures) ; Circles data from September 2010 (390 and 1515 ppb given by SPIRIT) and Crosses data from February 2011 (392 and 1520 ppb given by SPIRIT) show excellent reproducibility over 6 months and agreement between standards values (accuracy $<2 \%$ ) and SPIRIT values (accuracy $<$ $6 \%)$.

The full line (slope $=1$ ) in figure 6 a represents the line of perfect agreement between GC and standard pressurized cylinders vs our infrared spectrometer (SPIRIT). 


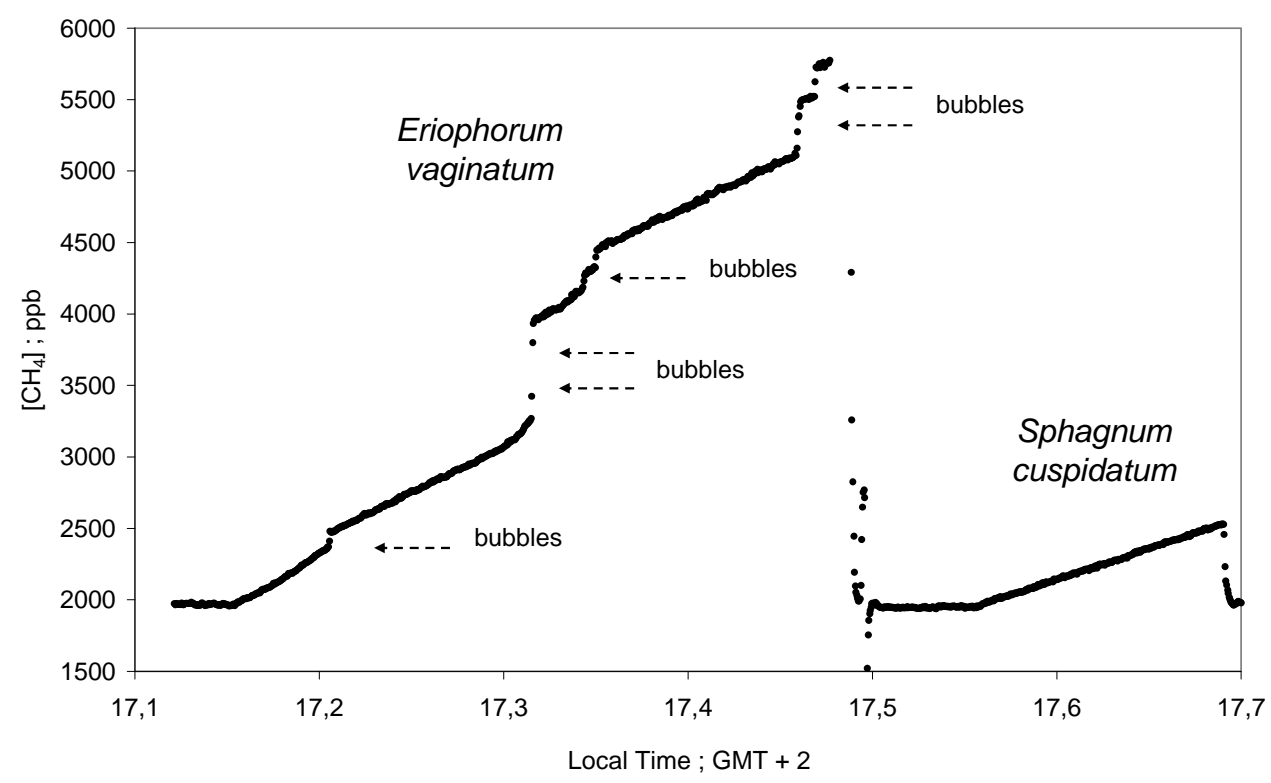

Figure 7. $\mathrm{CH}_{4}$ volume mixing ratio (ppb) as a function of Local Time during accumulation in the closed chamber (Eriophorum vaginatum plot and sphagnum cuspidatum plot, successively), on March 19, in La Guette's peatland. 


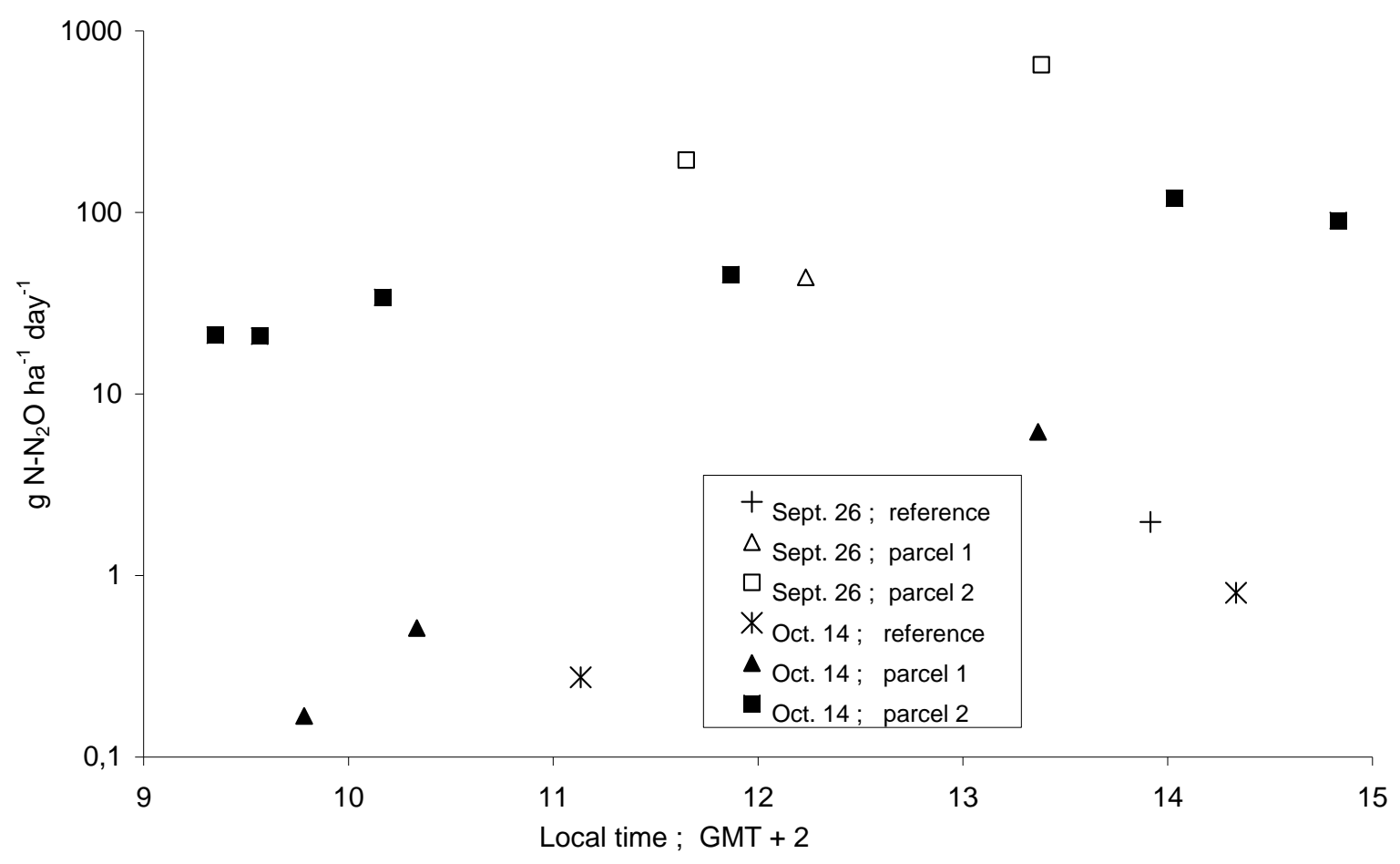

Figure 8. Time series of $\mathrm{N}_{2} \mathrm{O}$ fluxes for unfertilized soil (reference) and for 2 fertilized soils (parcels 1 and 2) with input of organic carbon (horse manure) and nitrogen $\left(\mathrm{NH}_{4} \mathrm{NO}_{3}\right)$ fertilizers. Parcel 2 is enriched with a loamy soil and put under strong anoxia compared to parcel 1 


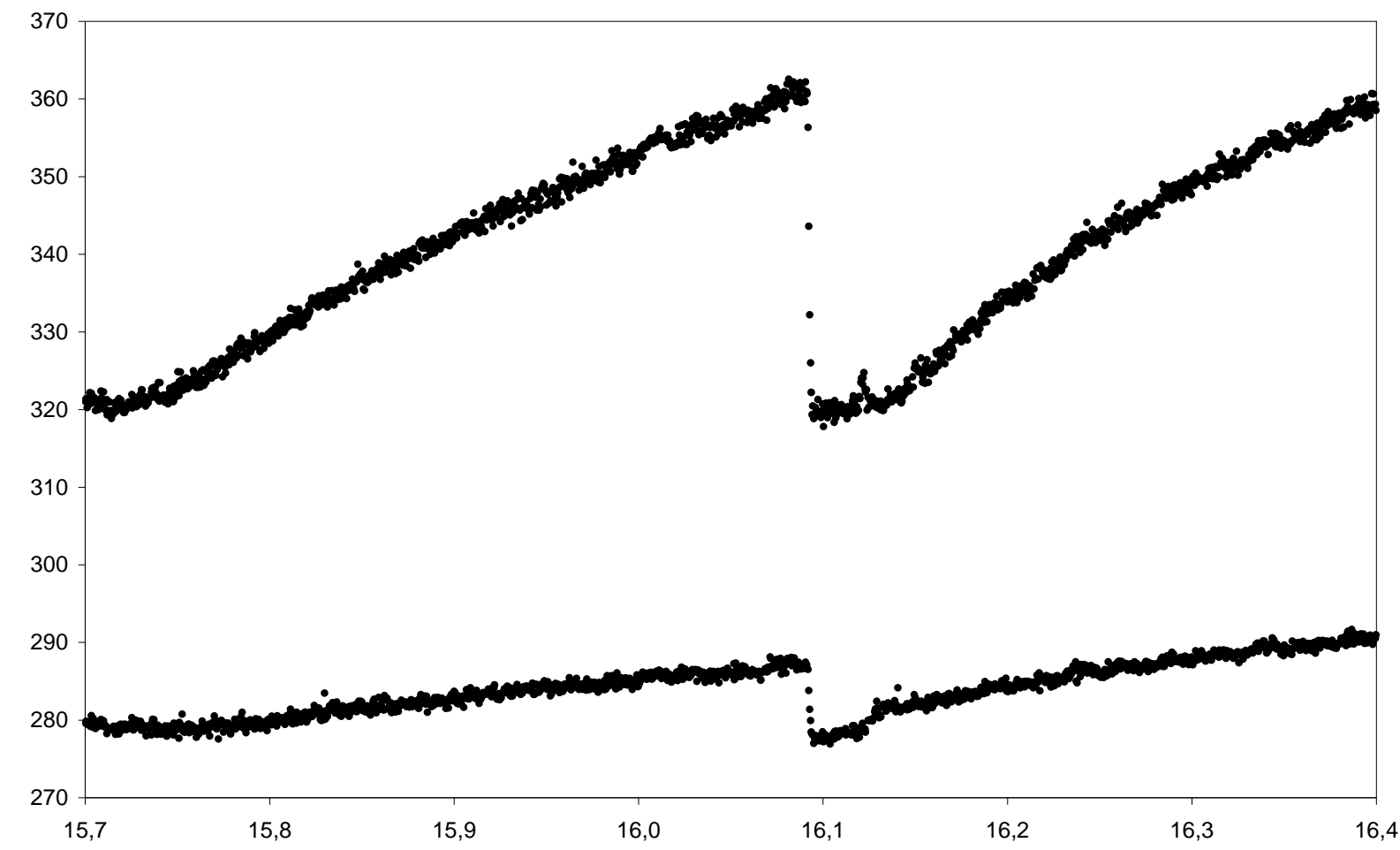

Figure 9a: $\mathrm{N}_{2} \mathrm{O}$ (upper plot) and $\mathrm{CH}_{4} / 7$ (lower plot) volume mixing ratios (ppb) versus time (U.T.) from a river nearby the Villebon experimental cultivated site (Beauce Chartraine and Faux Perche), March 18, 2010. 


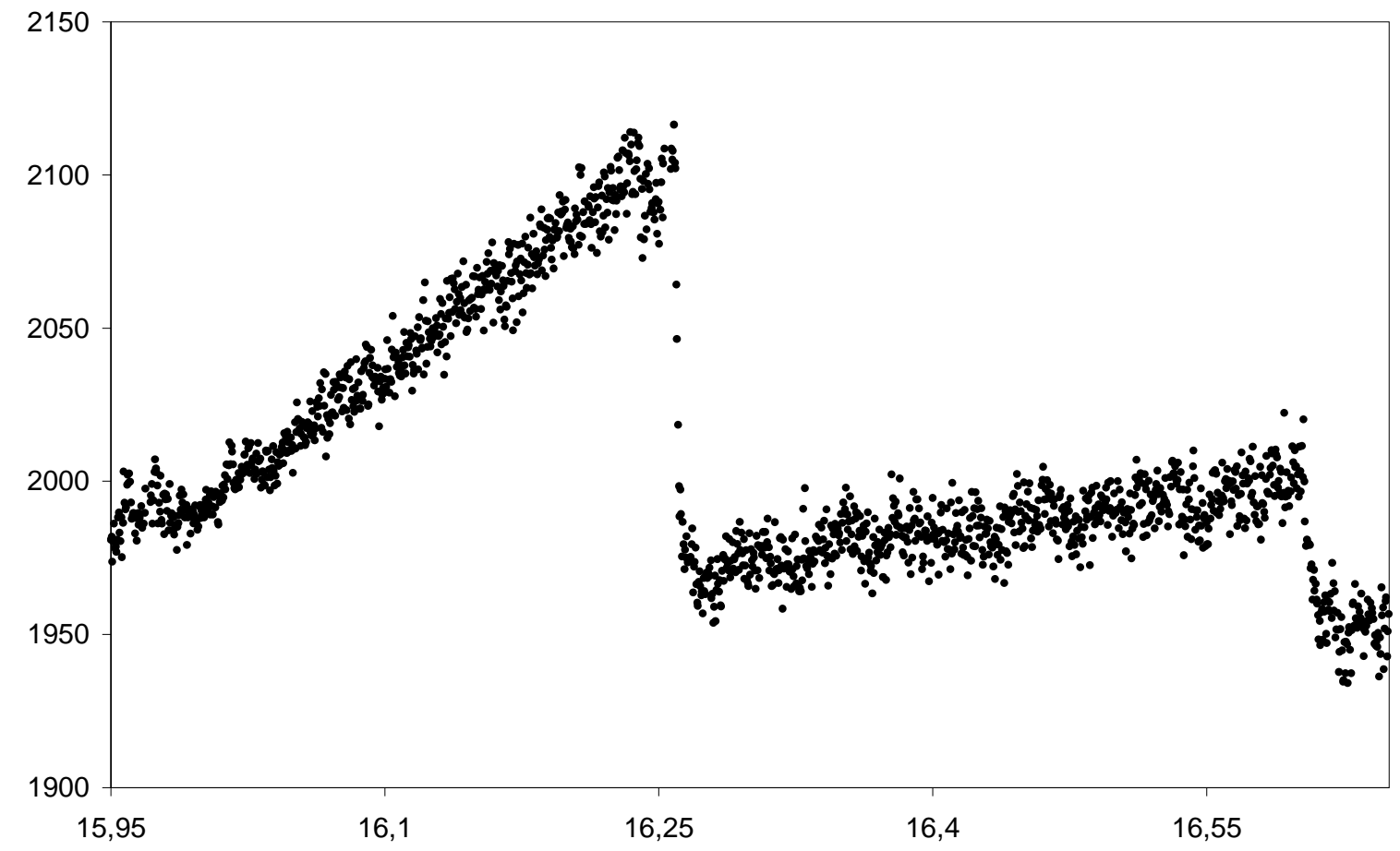

Figure 9b: $\mathrm{CH}_{4}$ concentrations (ppb) versus time (U.T.) from Lake Pavin in June 24, 2010 